\title{
Assimilation of water and dietary ions by the gastrointestinal tract during digestion in seawater-acclimated rainbow trout
}

\author{
Carol Bucking • John L. Fitzpatrick • \\ Sunita R. Nadella $\cdot$ Iain J. McGaw $\cdot$ \\ Chris M. Wood
}

Received: 29 September 2010/Revised: 31 December 2010/Accepted: 2 January 2011/Published online: 28 January 2011

(C) Springer-Verlag 2011

\begin{abstract}
Recent studies focusing on the consequences of feeding for ion and water balance in freshwater fish have revealed the need for similar comparative studies in seawater fish. A detailed time course sampling of gastrointestinal (GI) tract contents following the ingestion of a single meal of a commercial diet revealed the assimilation of both water and dietary ions $\left(\mathrm{Na}^{+}, \mathrm{Cl}^{-}, \mathrm{K}^{+}, \mathrm{Ca}^{2+}, \mathrm{Mg}^{2+}\right)$ along the GI tract of seawater-acclimated rainbow trout (Oncorhynchus mykiss) which had been fasted for 1 week. Consumption of the meal did not change the drinking rate. There was a large secretion of fluid into the anterior intestine and caecae (presumably bile and/or pancreatic
\end{abstract}

Communicated by I.D. Hume.

C. Bucking $\cdot$ J. L. Fitzpatrick $\cdot$ S. R. Nadella .

I. J. McGaw · C. M. Wood

Bamfield Marine Sciences Center, 100 Pachena Road,

Bamfield, BC V0R 1B0, Canada

C. Bucking - J. L. Fitzpatrick - S. R. Nadella · C. M. Wood

Department of Biology, McMaster University,

1280 Main Street West, Hamilton, ON L8S 4K1, Canada

Present Address:

J. L. Fitzpatrick

Center for Evolutionary Biology, School of Animal Biology,

University of Western Australia, Crawley, WA 6009, Australia

Present Address:

I. J. McGaw

Ocean Sciences Centre, Memorial University of Newfoundland,

St. John's, NL A1C 5S7, Canada

Present Address:

C. Bucking $(\bowtie)$

University of British Columbia, 2370-6270 University Blvd,

Vancouver, BC V6T 1K4, Canada

e-mail: carolbucking@gmail.com secretions). As a result, net assimilation (63\%) of the ingested water along the GI tract was lower than generally reported for fasted trout. $\mathrm{Mg}^{2+}$ was neither secreted into nor absorbed from the GI tract on a net basis. Only $\mathrm{K}^{+}$ (93\% assimilated) and $\mathrm{Ca}^{2+}(43 \%$ assimilated) were absorbed in amounts in excess of those provided by ingested seawater, suggesting that dietary sources of $\mathrm{K}^{+}$ and $\mathrm{Ca}^{2+}$ may be important to seawater teleosts. The oesophagus-stomach served as a major site of absorption for $\mathrm{Na}^{+}, \mathrm{Cl}^{-}, \mathrm{K}^{+}, \mathrm{Ca}^{2+}$, and $\mathrm{Mg}^{2+}$, and the anterior intestine and caecae as a major site of net secretion for all of these ions, except $\mathrm{Cl}^{-}$. Despite large absorptive fluxes of these ions, the ionic composition of the plasma was maintained during the digestion of the meal. The results of the present study were compared with previous work on freshwater-acclimated rainbow trout, highlighting some important differences, but also several similarities on the assimilation of water and ions along the gastrointestinal tract during digestion. This study highlights the complicated array of ion and water transport that occurs in the intestine during digestion while revealing the importance of dietary $\mathrm{K}^{+}$and $\mathrm{Ca}^{2+}$ to seawater-acclimated rainbow trout. Additionally, this study reveals that digestion in seawater-acclimated rainbow trout appears to compromise intestinal water absorption.

Keywords Ionoregulation - Marine - Osmoregulation · Prandial · Teleost

\section{Introduction}

Marine fish must drink seawater and subsequently absorb water along the intestine in order to replace water that is lost to the environment. While previous research has 
revealed much about these processes (e.g. Shehadeh and Gordon 1969; Grosell et al. 2009a), the majority of the studies examined unfed fish. However, the gastrointestinal (GI) tract of marine teleosts is important not only for osmoregulation, but also for feeding and digestion. The advantages of studying fasting fish to reveal the basic mechanisms of water and ion absorption are clear: complicating processes associated with ingestion of a meal are eliminated, such as large ion fluxes (Taylor and Grosell 2006) and acid-base disturbances (Bucking and Wood 2008). However, understanding gastrointestinal function from the limited position of the fasting state alone is unnatural and insufficient. For example, a number of studies have shown that feeding results in altered mineral and acid-base concentrations along the intestine of marine fish when compared to unfed fish (Dabrowski et al. 1986; Taylor and Grosell 2006; Taylor et al. 2007).

Feeding and digestion in seawater is likely to present the GI tract with several challenges. The first is an ion load associated with the feed. For example, a meal of sardines presents a $\mathrm{Ca}^{2+}$ load 40 -fold higher than average seawater levels (Taylor and Grosell 2006) and both squid and sardine meals present a $\mathrm{K}^{+}$load five- to sevenfold above seawater levels (Taylor and Grosell 2006), while seawater invertebrates also present elevated dietary ion loads. A typical commercial salmonid diet like the one used in the present study has a low water content but $\mathrm{Ca}^{2+}, \mathrm{K}^{+}$, and $\mathrm{Mg}^{2+}$ concentrations which are 17-fold, 11-fold, and 2-fold higher than in seawater, respectively. The second challenge associated with ingestion of a meal involves water absorption. The mechanisms of water processing leading to absorption include desalination of the ingested water by the oesophagus (e.g. Kirsch and Meister 1982; Ando et al. 2003), solute-linked water absorption in the intestine (e.g. Loo et al. 1996; Naftalin 2008), and intestinal $\mathrm{HCO}_{3}{ }^{-}$ secretion which functions to further drive intestinal water absorption by reducing the osmolality of the intestinal fluid though precipitation with calcium and conversion to $\mathrm{CO}_{2}$ (reviewed by Wilson et al. 2002; Grosell et al. 2009b). The secretion of $\mathrm{Na}^{+}$rich fluids during digestion such as bile or pancreatic fluids (or the ingestion of a particular diet high in $\mathrm{Na}^{+}$), may present the intestine with increased solute levels, further driving increased water absorption. In addition, a high dietary $\mathrm{Ca}^{2+}$ load may increase $\mathrm{HCO}_{3}{ }^{-}$ secretion and hence water absorption (Wilson et al. 2002). $\mathrm{HCO}_{3}{ }^{-}$secretion via the $\mathrm{Cl}^{-} / \mathrm{HCO}_{3}{ }^{-}$exchanger also depends on $\mathrm{pH}$ and $\mathrm{HCO}_{3}{ }^{-}$gradients (Wilson and Grosell 2003; Grosell et al. 2005), so if an increased gastric secretion of $\mathrm{HCl}$ associated with a protein meal occurs, then further water absorption by the intestine might be favoured. Nevertheless, in freshwater rainbow trout, digestion of commercial diets leads to a high intestinal chyme osmolality. If this occurs for seawater acclimated trout as well, it would have the potential to oppose the aforementioned processes (Bucking and Wood 2006a).

Finally, the digestion of a meal has been shown to increase the rate of intestinal $\mathrm{Cl}^{-} / \mathrm{HCO}_{3}{ }^{-}$exchange both in the flounder in vivo (Taylor and Grosell 2006) and in the trout (Bucking et al. 2009) and the gulf toadfish in vitro (Taylor and Grosell 2010), and may act as mechanism for relieving the alkaline tide (an increase in plasma $\mathrm{HCO}_{3}{ }^{-}$ concentrations associated with gastric acid secretion (reviewed by Niv and Fraser 2002). The increase in the rate of in vitro $\mathrm{Cl}^{-} / \mathrm{HCO}_{3}{ }^{-}$exchange seen in rainbow trout (Bucking et al. 2009) corresponded to an increase in fluid transport rate as well, indicating that in relieving the alkaline tide, the animals may be increasing their water absorption (Bucking et al. 2009).

In the present study, the effects of feeding on fluid balance and ionoregulation were investigated in seawateracclimated rainbow trout following the ingestion of a single meal of commercial pellets. The effects of feeding on drinking rate were measured and the gastrointestinal contents and blood plasma were sampled to reveal transport of ions and water across the GI tract epithelium during digestion, and to investigate possible ionoregulatory disturbances following the ingestion of a single meal. Water and electrolyte absorption or secretion along the tract were quantitatively determined by employing ballotini beads in the meal as non-absorbable inert markers, in a similar manner to our previous studies on freshwater-acclimated rainbow trout (Bucking and Wood 2006a, b, 2007). The fish had been fasted for 1 week prior to the meal, as in these previous studies on freshwater trout. This therefore allowed direct comparison of GI tract function in the same species acclimated to seawater versus freshwater, and fed under virtually identical conditions.

Our overall hypothesis was that feeding would alter the regulation of salt and water balance in a marine teleost fish. Specifically, we hypothesized that feeding would result in an increase in water assimilation along the GI tract, while the diet would provide additional $\mathrm{K}^{+}, \mathrm{Ca}^{2+}$, and $\mathrm{Mg}^{2+}$ that would be absorbed by the GI tract.

\section{Materials and methods}

Experimental animals and their maintenance

Rainbow trout of the steelhead strain (Oncorhynchus mykiss) were obtained from the Robertson Creek Hatchery, Port Alberni, BC, CA and were housed in outdoor tanks ( 2001$)$ at the Bamfield Marine Sciences Centre where they were subjected to natural photoperiods (April-July). The tanks were individually supplied with aeration and both fresh- and seawater sources $\left(\sim 12^{\circ} \mathrm{C}\right)$. The animals 
(50-150 g body mass) were initially acclimated to freshwater $(0 \mathrm{ppt}$, dechlorinated tap water). Through incremental increases in the total salinity of the tank water ( $\sim 10 \%$ every 2 weeks), the trout were gradually acclimated to full strength seawater (31-32\%, Bamfield Marine Sciences Centre seawater; $\mathrm{Na}^{+}=489 \pm 5 ; \mathrm{Cl}^{-}=539 \pm$ $8 ; \mathrm{K}^{+}=9.4 \pm 1.2 ; \mathrm{Ca}^{2+}=10.8 \pm 1.1 ; \mathrm{Mg}^{2+}=52 \pm 3$ mmol $1^{-1}$ ). With the exception of 3 days following each salinity increase when feeding was suspended, the animals were fed a $2 \%$ body weight ration of commercial fish food ( 3 pt floating pellets, EWOS Pacific, Surrey, British Columbia, Canada) every $48 \mathrm{~h}$. The measured ionic composition of the food is reported below.

\section{Experimental procedures}

\section{Series 1: Postprandial drinking}

Once the animals were acclimated to full strength seawater, they were placed on a month-long feeding schedule of a $2 \%$ body mass ration of repelleted commercial fish feed, fed at the same time every $48 \mathrm{~h}$. The commercial fish feed was repelleted to mimic the feed that was used in experimental series 2. Briefly, repelleting consisted of placing commercial fish feed, which had been ground into a fine powder using a Braun PowerMax Jug Blender (Gillette Company, Boston, USA), into a commercial pasta maker (Popeil Automatic Pasta Maker; Ronco Inventions, Catsworth, USA) with double distilled water at a ratio of 2:1 (feed:water). The mixture was mixed evenly ( $\sim 60 \mathrm{~min}$ ), extruded and then shaped to approximate three point-sized fish feed pellets. The repelleted feed was then air-dried for 2 days and stored in a $-20^{\circ} \mathrm{C}$ freezer until use.

Following the 1 month feeding schedule, fish were not fed for 1 week to clear the GI tract and then were either fed to satiation with the repelleted fish fed ( $\sim 5 \%$ body mass meal) or sham fed (tank lid was opened but no food was added; Table 1). This was referred to as time $0 \mathrm{~h}$. At various time points before $(-0.5 \mathrm{~h})$ and after $(2,4,8 \mathrm{~h})$ feeding or sham-feeding, water flow was suspended and polyethylene glycol 4000 (PEG, Sigma; $1 \mathrm{mg} \mathrm{ml}^{-1}$ ) was added to one of several tanks (Table 1). The PEG additions were at various times following feeding (see above timeline) so that the maximum exposure period was $4 \mathrm{~h}$. This inert drinking rate marker has been widely used in several species of marine fish including trout (e.g. Webb and Wood 2000), and has been shown by terminal blood sampling not to be absorbed across the gastro-intestinal tract of seawater trout (Wilson et al. 1996). Subsequently, water samples were taken every hour, and analyzed for the concentration of PEG $\left(\mathrm{mg} \mathrm{ml}^{-1}\right)$ to ensure consistent concentrations were maintained throughout the water column. Following the spike of PEG into the water, individual fish $(N=7)$ were removed from the tanks at $0,2,4,8$, and $12 \mathrm{~h}$ following feeding or sham-feeding (Table 1) and sacrificed by cephalic concussion. MS-222 anesthesia was not employed because preliminary experiments demonstrated that it resulted in vomiting in recently fed fish. The entire GI tract was then exposed through a mid-line incision from mouth to anus. Each GI tract section was identified (oesophagusstomach, anterior intestine including pyloric caecae, mid intestine and posterior intestine) and ligated at both ends with surgical silk to prevent fluid and/or chyme movement between the sections. Note that while the oesophagus contained negligible fluid, its function is thought to be absorptive in marine teleosts, and therefore its function cannot be distinguished from that of the fluid-containing stomach in the present experimental design. The contents (chyme or fluid) of each section were removed, weighed, and centrifuged $(13,000 \mathrm{~g}, 1 \mathrm{~min}$.) before the supernatant was decanted and analyzed for the appearance of PEG, which was quantified by a colorimetric assay according to Malawer and Powell (1967) and modified according to Buxton et al. (1979). The remaining chyme was then ovendried $\left(60^{\circ} \mathrm{C}\right.$ for $\left.48 \mathrm{~h}\right)$ to determine dry weight. Analysis of

Table 1 Density of fish, feeding and sampling schedule of series 1 , and drinking rate $\left(\mathrm{ml} \mathrm{kg}^{-1} \mathrm{~h}^{-1}\right)$ of fed (F) and sham-fed (S) fish

\begin{tabular}{|c|c|c|c|c|c|c|c|c|}
\hline & \multicolumn{8}{|l|}{ Tank } \\
\hline & A & B & C & D & $\mathrm{E}$ & $\mathrm{F}$ & G & $\mathrm{H}$ \\
\hline Number of fish in tank & 20 & 20 & 20 & 20 & 20 & 20 & 20 & 20 \\
\hline Number of fish sampled & 7 & 7 & 7 & 7 & 7 & 7 & 7 & 7 \\
\hline Time fed $(\mathrm{F})$ or sham fed $(\mathrm{S})$ & $0 \mathrm{~h}(\mathrm{~F})$ & $0 \mathrm{~h}(\mathrm{~F})$ & $0 \mathrm{~h}(\mathrm{~F})$ & $0 \mathrm{~h}(\mathrm{~F})$ & $0 \mathrm{~h}(\mathrm{~S})$ & $0 \mathrm{~h}(\mathrm{~S})$ & $0 \mathrm{~h}(\mathrm{~S})$ & $0 \mathrm{~h}(\mathrm{~S})$ \\
\hline Time PEG added and water flow stopped (h) & -0.5 & 2 & 4 & 8 & -0.5 & 2 & 4 & 8 \\
\hline Time fish sampled (h) & 2 & 4 & 8 & 12 & 2 & 4 & 8 & 12 \\
\hline Water [PEG] $\left(\mathrm{mg} \mathrm{ml}^{-1}\right)$ & $1.0 \pm 0.2$ & $0.9 \pm 0.2$ & $1.1 \pm 0.3$ & $1.0 \pm 0.1$ & $0.9 \pm 0.2$ & $1.1 \pm 0.1$ & $1.1 \pm 0.2$ & $1.1 \pm 0.2$ \\
\hline Drinking rate $\left(\mathrm{ml} \mathrm{kg}^{-1} \mathrm{~h}^{-1}\right)$ & $2.2 \pm 1.2$ & $2.1 \pm 1.3$ & $2.4 \pm 1.2$ & $2.4 \pm 1.0$ & $2.0 \pm 0.8$ & $2.3 \pm 0.9$ & $1.9 \pm 0.8$ & $2.2 \pm 0.9$ \\
\hline
\end{tabular}

Times are in hours. Fish were fed (F) or sham fed (S) at $0 \mathrm{~h}$. [PEG] in the water $\left(\mathrm{mg} \mathrm{ml}^{-1}\right)$ was measured each hour and averaged over the flux period. $N=7$ for each sample time (2, 4, 8 , and $12 \mathrm{~h}$ following "feeding") 
contents of the three intestinal compartments revealed negligible concentrations of PEG; all PEG was present in the oesophagus-stomach. As a result drinking rates $\left(\mathrm{ml} \mathrm{kg} \mathrm{kg}^{-1} \mathrm{~h}^{-1}\right.$ ) for fed and unfed fish were calculated as the ratio of PEG found in the oesophagus-stomach:PEG found in the water, factored by the volume of water in the oesophagus-stomach, fish mass, and time:

Drinking rate $(\mathrm{DR})=\frac{\left(\frac{[\mathrm{PEG}]_{\mathrm{s}}}{[\mathrm{PEG}]_{\mathrm{w}}} V_{\mathrm{w}}\right)}{M T}$

where $[\mathrm{PEG}]_{\mathrm{S}}$ was the concentration of PEG in the oesophagus-stomach $\left(\mathrm{mg} \mathrm{ml}^{-1}\right)$ and $[\mathrm{PEG}]_{\mathrm{w}}$ was the concentration of PEG in the surrounding water $\left(\mathrm{mg} \mathrm{ml}^{-1}\right)$. $V_{\mathrm{w}}$ was the volume of water found in the oesophagusstomach $(\mathrm{ml})$ measured as total volume collected (unfed fish) or as the difference between the wet weight of the chyme and the dry weight of the chyme (fed fish). $M$ was the mass of the fish $(\mathrm{kg})$ and $T$ was the time period (h). Although the entire GI tract was analyzed, only the oesophagus-stomach contained measurable concentrations of PEG. Additionally, the ratio of $[\mathrm{PEG}]_{\mathrm{s}}:[\mathrm{PEG}]_{\mathrm{w}}$ was used to estimate the net amount of water that was secreted or absorbed by the oesophagus-stomach during digestion.

\section{Series 2: net dietary handling of water and ions} during digestion

Concurrent to series 1, a separate group of animals were also not fed for 1 week following the 1 month of scheduled feeding. The trout were then fed to satiation $(\sim 5 \%$ body mass) with an experimental diet reformulated as described by Bucking and Wood (2006a, b, 2007), consisting of repelleted commercial fish feed (as in series 1) with the additional incorporation of leaded glass ballotini beads $(0.40-0.45 \mathrm{~mm}$ in diameter; $4 \%$ ratio of beads to dry food weight; Jencons Scientific, Pennsylvania, USA). To quantify the incorporation of ballotini beads into the feed, random subsamples (of various dry weights) of the experimental diet were X-rayed (LIXI PS500 OS X-ray system; Huntley, IL, USA) and the images digitally recorded using fluoroscopy processing software (Poynting products, Oak Park, IL, USA). The number of beads observed was then correlated with the dry weights of the pellets to ensure a linear relationship $(y=0.0116 x+1.2$, $\left.R^{2}=0.931\right)$.

Sampling consisted of obtaining chyme samples from trout before and after feeding, as previously described (Bucking and Wood 2006a, b, 2007). Individual trout ( $N=7$ per each time period) were removed from the holding tanks and sampled immediately prior to feeding $(0 \mathrm{~h})$, and at 2, 4, 8, 12, 24, $48 \mathrm{~h}$ following feeding. Fish were sacrificed by cephalic concussion followed by blood sampling via caudal puncture with an iced, heparinized Hamilton syringe. The whole blood was immediately centrifuged $(13,000 \mathrm{~g} ; 30 \mathrm{~s})$ to obtain plasma which was then decanted, placed in liquid nitrogen and stored at $-80^{\circ} \mathrm{C}$ until analysis. The gastrointestinal tract was then exposed and each region ligated as described above. The entire GI tract was then removed via incisions at the esophagus and the rectum and placed on ice. The GI tract was subsequently X-rayed using a LIXI fluoroscope. Technical specifications for X-ray were $35 \mathrm{kV}$ tube voltage, $155 \mu \mathrm{A}$ tube current with a $5 \mathrm{~cm}$ focal window. The images were digitally recorded and the number of ballotini beads in each gut section was quantified manually.

The contents of each gut section (chyme or fluid) were then removed and the $\mathrm{pH}$ of the GI tract contents measured by immersing a microelectrode set (consisting of an esophageal $\mathrm{pH}$ electrode and a micro-reference electrode; Microelectrode Inc., New Hampshire, USA) directly into the chyme or endogenous fluids. The microelectrodes were calibrated with precision buffers (Radiometer-Copenhagen, Copenhagen, Denmark) thermostatted to the experimental temperature $\left(12^{\circ} \mathrm{C}\right)$, and connected to a Radiometer $\mathrm{pHM}$ $84 \mathrm{pH}$ meter.

A subsample of the GI tract contents was taken and centrifuged to obtain a fluid phase of the chyme, which was placed in liquid nitrogen and subsequently stored at $-80^{\circ} \mathrm{C}$ for ionic content analysis. The remaining contents of each gut section were weighed to obtain a wet chyme weight $(\mathrm{g})$ or fluid volume $(\mathrm{ml})$. The wet chyme was then ovendried at $60^{\circ} \mathrm{C}$ to constant weight and the water content was determined. The remaining dried chyme was then aciddigested (5 volumes of $1 \mathrm{~N} \mathrm{HNO}_{3}$ (Fisher, Pennsylvania, USA, analytical grade); $60^{\circ} \mathrm{C}$ for $48 \mathrm{~h}$ ), centrifuged $(13,000 \mathrm{~g}, 60 \mathrm{~s})$, and the supernatant analyzed for chyme ion content.

Ion concentrations in the food, the chyme (both in

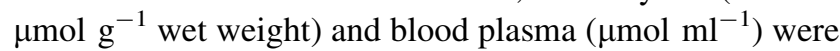
determined by using a Varian 1275 Atomic Absorption Spectrophotometer $\left(\mathrm{Na}^{+}, \mathrm{K}^{+}, \mathrm{Ca}^{2+}, \mathrm{Mg}^{2+}\right)$, and a chloridometer (CMT 10 Chloride Titrator, Radiometer, Copenhagen, Denmark; $\mathrm{Cl}^{-}$). As per standard methodology, $\mathrm{LaCl}_{3}(1 \%)$ was added to all samples when measuring $\mathrm{Ca}^{2+}$ and $\mathrm{Mg}^{2+}$, while $\mathrm{CsCl}(0.1 \%)$ was added when measuring $\mathrm{K}^{+}$.

The relative concentration of water $\left(R_{\mathrm{w}} ; \mathrm{ml} \mathrm{bead}^{-1}\right)$ provided the relative amount of water found in the chyme in relation to the inert marker (ballotini beads; Bucking and Wood 2006a):

Relative water concentration $\left(R_{\mathrm{w}}\right)=\frac{\left(W_{\mathrm{c}} M_{\mathrm{w}}\right)}{X_{\mathrm{s}}}$

where " $W_{\mathrm{c}}$ " was the water content $\left(\mathrm{ml} \mathrm{g}^{-1}\right.$ wet mass) found in a chyme or food sample, " $M_{\mathrm{w}}$ " was the wet mass 
of the chyme sample $(\mathrm{g})$ and " $X_{\mathrm{s}}$ " was the bead number in the chyme sample.

The total flux of water $\left(F_{\mathrm{w}} ; \mathrm{ml} \mathrm{kg}^{-1}\right)$ into each section of the GI tract at each time point provided the amount of water that was secreted or absorbed in each section when compared to the preceding compartment of the GI tract (Bucking and Wood 2006a):

Total water flux $\left(F_{\mathrm{w}} ; \mathrm{ml} \mathrm{kg}^{-1}\right)=\frac{\left(R_{\mathrm{w} 1}-R_{\mathrm{w} 2}\right) X_{\mathrm{s} 1}}{M}$

where " $R_{\mathrm{w} 1}$ " was the relative concentration of water $\left(\mathrm{ml}\right.$ bead $\left.^{-1}\right)$ in the GI tract section of interest and " $R_{\mathrm{w} 2}$ " was the relative concentration of water $\left(\mathrm{ml} \mathrm{bead}^{-1}\right)$ in the preceding section at the same time point, " $X_{\mathrm{s} 1}$ " was the total number of beads in the section of interest, and $M$ was the fish mass $(\mathrm{kg})$. The "preceding compartment" for the oesophagus-stomach at $2 \mathrm{~h}$ was the ingested food, and thereafter the oesophagus-stomach itself at the previous time point.

Net absorptive water fluxes (negative values) and net secretory water fluxes (positive values) were summed across all time points and in all the GI tract sections (signs considered) and then factored by the total water ingested. This provided the total water absorbed as a percentage of water ingested, while taking into account water that was secreted by the GI tract, i.e. net water assimilation.

The relative ion concentration in the chyme (or food; $R_{\mathrm{c}}$; $\mu \mathrm{mol}$ bead $^{-1}$ ) provided the concentration of the ions in relation to the inert non-absorbable marker (Bucking and Wood 2006b, 2007):

Relative ion concentration $\left(R_{\mathrm{c}}\right)=I_{\mathrm{c}}\left(\frac{M_{\mathrm{w}}}{X_{\mathrm{S}}}\right)$

where " $I_{\mathrm{c}}$ " was the ion concentration ( $\mu \mathrm{mol} \mathrm{g}{ }^{-1}$ wet mass) found in a chyme or food sample, " $M_{\mathrm{w}}$ " was the wet mass of the chyme sample $(\mathrm{g})$ and " $X_{\mathrm{s}}$ " was the bead number in the chyme sample.

Subsequently, total ion fluxes $\left(F_{\text {Is }} ; \mathrm{mmol} \mathrm{kg}^{-1}\right)$ in the oesophagus-stomach provided the amount of ion that was secreted or absorbed in the oesophagus-stomach, while taking into account the ions that were added by drinking the surrounding medium:

Total ion flux $\left(F_{\mathrm{Is}}\right)=\frac{\left[\left(I_{\mathrm{s} 1}-\left(I_{\mathrm{s} 2}+I_{\mathrm{D}}\right)\right) / 1,000 X_{\mathrm{s} 1}\right]}{M}$

where " $I_{\mathrm{s} 1}$ " was the relative concentration of each ion $\left(\mu \mathrm{mol} \mathrm{bead}{ }^{-1}\right)$ in the oesophagus-stomach at the time point of interest and " $I_{\mathrm{s} 2}$ " was the relative concentration of each ion $\left(\mu \mathrm{mol} \mathrm{bead}{ }^{-1}\right)$ in the oesophagus-stomach at the previous time point. " $I_{\mathrm{D}}$ " was the relative concentration of each ion $\left(\mu \mathrm{mol} \mathrm{bead}{ }^{-1}\right)$ added to the oesophagus-stomach between the two time points based on drinking rates described above and the known ionic composition of the surrounding water. " $X_{\mathrm{s} 1}$ " was the total number of beads in the oesophagus and stomach at the time point of interest, and $M$ was the fish mass $(\mathrm{kg})$. The "preceding time point" for the oesophagus-stomach at $2 \mathrm{~h}$ was the ingested food.

Total ion fluxes $\left(\mathrm{mmol} \mathrm{kg}^{-1}\right)$ along the intestinal tract provided the amount of ion that was secreted or absorbed in each GI tract section when compared spatially to the preceding compartment of the GI tract (Bucking and Wood 2006b, 2007):

Total ion flux $\left(F_{\mathrm{Ii}}\right)=\frac{\left[\left(I_{\mathrm{s} 1}-I_{\mathrm{s} 2}\right) / 1,000 X_{\mathrm{s} 1}\right]}{M}$

where " $I_{\mathrm{s} 1}$ " was the relative concentration of each ion $\left(\mu \mathrm{mol}\right.$ bead $\left.^{-1}\right)$ in the GI tract section of interest and " $I_{\mathrm{s} 2}$ " was the relative concentration of each ion $\left(\mu \mathrm{mol} \mathrm{bead}^{-1}\right)$ in the preceding section at the same time point, " $X_{\mathrm{s} 1}$ " was the total number of beads in the section of interest, and $M$ was the fish mass $(\mathrm{kg})$.

Net ion assimilation provided the total percentage of the ion absorbed by the animal when compared to the total ingested. It was based on the difference between total net absorptive fluxes and net secretory fluxes calculated in Eq. 6 and factored by the total concentration of the ion consumed (both imbibed with water and consumed in the diet).

No significant difference was found in the ionic compositions of any diets $\left[\mathrm{Na}^{+}=243 \pm 6 ; \mathrm{Cl}^{-}=197 \pm 4\right.$; $\mathrm{K}^{+}=99.2 \pm 3 ; \mathrm{Ca}^{2+}=186 \pm 6 ; \mathrm{Mg}^{2+}=108 \pm 5 \mu \mathrm{mol}$ $\mathrm{g}^{-1}$ wet weight $\left.(N=21)\right]$ or in the water content $[13.7 \pm$ $1.6 \%(N=21)]$.

It is also important to note that all flux calculations yield absolute values-i.e. they were not factored by time.

\section{Statistics}

Data have been reported as means \pm SEM $(N=$ number of fish), unless otherwise stated. All data passed normality and homogeneity tests before statistical analyses were performed using SigmaStat (version 3.1). The effect of feeding on drinking rate during series 1 was examined using a one-way ANOVA, followed by a HSD post-hoc test (Tukey's Honest Significant Difference). The effect of location (i.e. gut section) on ion concentration during series 2 was tested using a one-way ANOVA with GI tract section as the main variable examined at each time point, both in the total chyme as well as the fluid phase. Within each GI tract section, the effect of time on ion concentration as well as the difference between total chyme and fluid phase ion concentrations were tested using a two-way ANOVA with time and total chyme versus fluid phase as the two variables. Temporal changes in plasma ionic composition and GI tract $\mathrm{pH}$ were examined with a one-way ANOVA. The ionic composition of each diet, the comparison of ion 
composition between chyme and seawater at each time point, and comparing drinking rates between the experimental series, were evaluated using paired and unpaired $t$ tests as appropriate. All of the statistical tests were followed by a HSD post-hoc test (Tukey's Honest Significant Difference; ANOVA) or Bonferroni corrections ( $t$ tests) as appropriate. Values were considered significantly different at $P<0.05$.

\section{Results}

Drinking and water handling along the GI tract

The drinking rate of unfed seawater-acclimated rainbow trout was maintained at a mean rate of $2.1 \pm$ $0.4 \mathrm{ml} \mathrm{kg}^{-1} \mathrm{~h}^{-1}(N=28$; Table 1$)$ and did not change significantly during the experimental period. Following feeding to satiation, fed fish ingested an average ration of $3.0 \pm 0.4 \%$ body weight. The mean drinking rate of fed fish $\left(2.3 \pm 0.6 \mathrm{ml} \mathrm{kg}^{-1} \mathrm{~h}^{-1}\right.$; Table 1) which was not significantly different from that of unfed fish, also remained stable over time. Interestingly, the ratio of the concentration of PEG $\left(\mathrm{mg} \mathrm{ml}^{-1}\right)$ found in the oesophagus-stomach fluid of fed fish versus the concentration of PEG $\left(\mathrm{mg} \mathrm{ml}^{-1}\right)$ found in the external water was approximately $1(0.98 \pm 0.2, N=28)$ suggesting that there was little to no net secretion and/or absorption of fluid by the lumen of the oesophagus-stomach, or that the rates and/or magnitude of secretion and absorption were closely matched.
Feeding to satiation resulted in an average ingested ration of $3.41 \pm 0.20$ (21) \% body weight, measured by the summation of bead counts in the oesophagus, stomach, and caeca up to $8 \mathrm{~h}$ in series 2 (i.e. in the absence of defecation). Water fluxes into the oesophagus-stomach showed net addition of water at all time points (Fig. 1). Overall, there was a net addition of $\sim 71 \mathrm{ml} \mathrm{kg}^{-1}$ into the oesophagus-stomach of fed seawater fish over $48 \mathrm{~h}$ (Fig. 1). Based on the assumption that endogenous net water secretion was minimal (see above), a drinking rate of $1.5 \pm 0.7 \mathrm{ml} \mathrm{kg}^{-1} \mathrm{~h}^{-1}(N=48)$ was calculated. Although this was lower than that measured in series 1 , the difference proved to be statistically insignificant. As there was no significant difference between the first and second experimental series, an average fed drinking rate of $1.8 \pm 0.7 \mathrm{ml} \mathrm{kg}^{-1} \mathrm{~h}^{-1}$ (an average of all drinking rates measured and calculated from fed fish in both series) was used to calculate all subsequent ion fluxes (Eq. 5). Approximately $7 \mathrm{ml} \mathrm{kg}^{-1}$ of water was secreted into the anterior intestine and caecae, cumulated over $48 \mathrm{~h}$, adding to the water load found in the GI tract (Fig. 1). In contrast, the mid and posterior intestinal sections showed a net absorptive flux of water at all time points $\left(52 \mathrm{ml} \mathrm{kg}^{-1}\right.$ combined over $48 \mathrm{~h}$ and between both GI tract sections; Fig. 1). Overall, a net total of $78 \mathrm{ml} \mathrm{kg}^{-1}\left(4.4 \mathrm{ml} \mathrm{kg}^{-1}\right.$ supplied by the diet itself) was ingested and/or secreted to the GI tract during feeding and digestion, while only $52 \mathrm{ml} \mathrm{kg}^{-1}$ was absorbed. A net gastrointestinal absorption of $45 \mathrm{ml} \mathrm{kg}^{-1}$ (after accounting for the anterior intestine secretions) resulted in a net assimilation of $\sim 63 \%$ of the water ingested.
Fig. 1 Flux of water $\left(\mathrm{ml} \mathrm{kg}^{-1}\right)$ into each GI tract section over various time intervals during the digestion of a single meal by seawater rainbow trout. Positive values indicate secretion while negative values indicate absorption. Feeding occurred immediately after $0 \mathrm{~h}$. Note that these are absolute fluxes over the specified time intervals, so individual statistical comparisons are not appropriate as intervals differ. Mean $\pm 1 \operatorname{SEM}(N=7)$

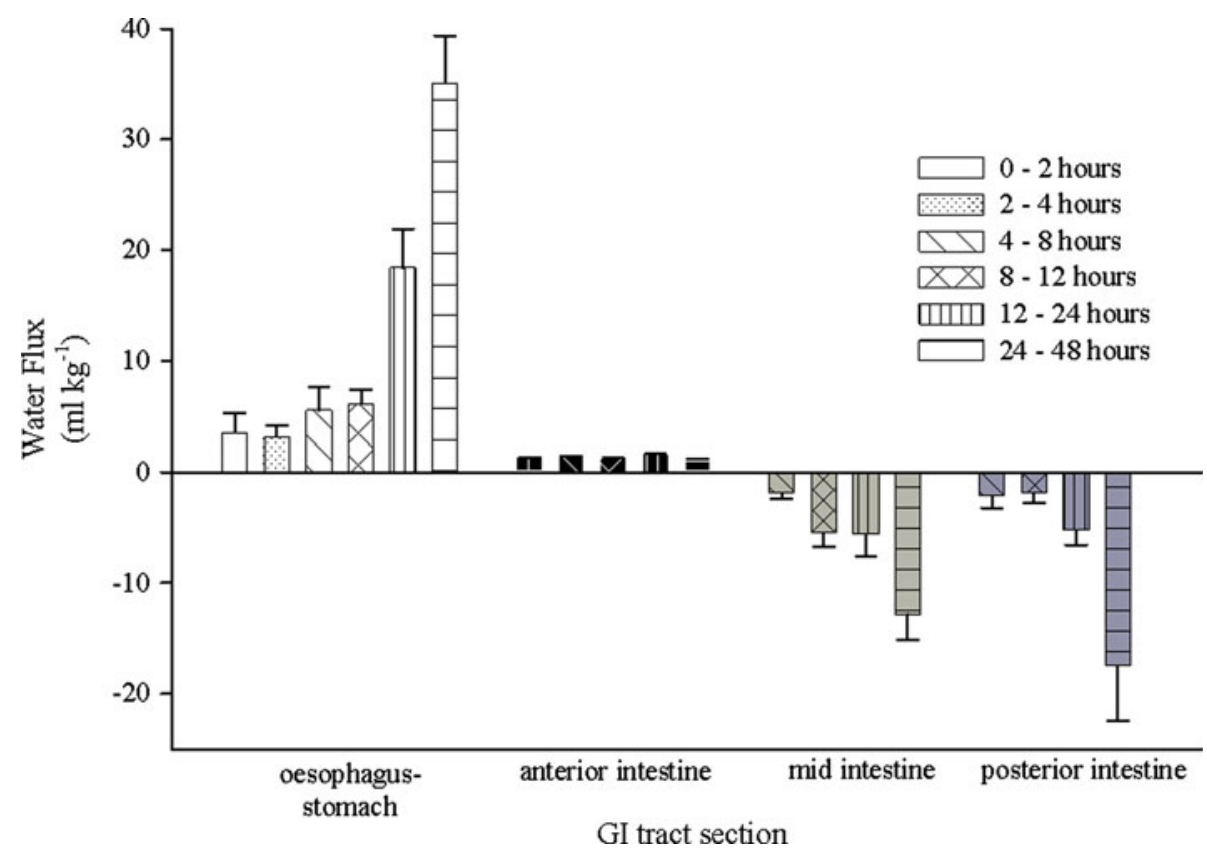


Dietary ion handling along the GI tract

The ionic concentrations of the fluid phase $\left(\mathrm{mmol} \mathrm{l}^{-1}\right)$ of the chyme as well as the total chyme $\left(\mathrm{mmol} \mathrm{kg}^{-1}\right)$ are reported in Table 2, together with measured values for seawater composition. In general, the concentration of all ions in both the total chyme as well as the fluid phase significantly decreased as digesta moved along the GI tract, although this trend was much more variable for the divalent cations (Table 2). Furthermore, for all ions, concentrations in the fluid phase were generally lower than in the total chyme; a trend significant at most time points, especially along the intestine. When examining the total chyme found in the oesophagus-stomach, the concentrations of $\mathrm{K}^{+}$, $\mathrm{Ca}^{2+}$, and $\mathrm{Mg}^{2+}$ were greater than or equal to those in seawater, whereas those of $\mathrm{Na}^{+}$and $\mathrm{Cl}^{-}$were significantly less than those in seawater (Table 2). In the fluid phase of gastric chyme, the same was true for $\mathrm{Na}^{+}$and $\mathrm{Cl}^{-}$, but $\mathrm{K}^{+}$ concentrations were similar to seawater levels, whereas $\mathrm{Ca}^{2+}$ and $\mathrm{Mg}^{2+}$ concentrations were initially lower than seawater levels but rose to exceed them later in the $48 \mathrm{~h}$ experimental period (Table 2).

There was a general trend of reduction in ion concentration with time and with distance along the intestine for all ions except $\mathrm{Mg}^{2+}$ throughout the $48 \mathrm{~h}$; however, there were considerable quantitative and qualitative differences among individual ions and phases (Table 2). However, as both the solid and fluid components were modified in volume as chyme moved along the tract, it is impossible to interpret trends from changes in concentration alone. Therefore, detailed quantitative examination of the changes was undertaken with respect to an inert marker (ballotini beads; see "Materials and methods") and summarized as fluxes-i.e. net absorptive or secretory movements of each ion over each time period in each section of the gastrointestinal tract (Fig. 2), as outlined below.

As the measured concentration of $\mathrm{Na}^{+}$found in the prepared diet was $243 \pm 6(21) \mu \mathrm{mol} \mathrm{g}{ }^{-1}$ original food weight, an ingested meal of $3.4 \%$ corresponds to an average $\mathrm{Na}^{+}$intake of approximately $8.3 \mathrm{mmol} \mathrm{kg}^{-1}$ fish weight. Imbibed water (based on an average drinking rate of $1.8 \mathrm{ml} \mathrm{kg}^{-1} \mathrm{~h}^{-1}$ and a water composition of $489 \mu \mathrm{mol} \mathrm{ml}{ }^{-1}$ ) provided an additional exogenous $\mathrm{Na}^{+}$ load of $42 \mathrm{mmol} \mathrm{kg}^{-1}$. The net flux of $\mathrm{Na}^{+}$in the oesophagus-stomach was negative at all time points, indicating continuous absorption during digestion ( $35 \mathrm{mmol} \mathrm{kg}{ }^{-1}$ total; Fig. 2a). In contrast, $\mathrm{Na}^{+}$was secreted into the anterior intestine and caecae ( $\sim 5 \mathrm{mmol} \mathrm{kg}^{-1}$; Fig. 2a), while the mid and posterior intestinal segments also absorbed $\mathrm{Na}^{+}\left(11 \mathrm{mmol} \mathrm{kg}{ }^{-1}\right.$ total for both sections; Fig. 2a). Based on this, the total addition of $\mathrm{Na}^{+}$to the GI tract was $56 \mathrm{mmol} \mathrm{kg}-1$ (including secretions from the anterior intestine). The total absorption by the GI tract was $47 \mathrm{mmol} \mathrm{kg}^{-1}$ (Fig. 2a), while the total secretion was $5 \mathrm{mmol} \mathrm{kg}^{-1}$ resulting in an average net absorption of $43 \mathrm{mmol} \mathrm{kg} \mathrm{m}^{-1}$ by the GI tract. The total amount of $\mathrm{Na}^{+}$ingested was $50 \mathrm{mmol} \mathrm{kg}{ }^{-1}$ resulting in an overall $86 \%$ net assimilation of $\mathrm{Na}^{+}$, of which dietary $\mathrm{Na}^{+}$was a small fraction (8.3 vs. $42 \mathrm{mmol} \mathrm{kg}^{-1}$ ).

The flux of $\mathrm{Cl}^{-}$into the oesophagus-stomach was initially secretory ( $2 \mathrm{~h}$ following feeding), but $\mathrm{Cl}^{-}$was subsequently absorbed from the oesophagus-stomach on a net basis (Fig. 2b). Net assimilation of $\mathrm{Cl}^{-}$from the oesophagus-stomach was slightly lower than that for $\mathrm{Na}^{+}$ (28 mmol kg ${ }^{-1}$; Fig. 2b), despite a similar dietary load $\left(6.6 \mathrm{mmol} \mathrm{kg}{ }^{-1}\right)$ and greater $\mathrm{Cl}^{-}$levels in the ingested water. This likely reflected the secretion of $\mathrm{Cl}^{-}$in the form of $\mathrm{HCl}$ in addition to the $\mathrm{Cl}^{-}$absorbed from the ingested

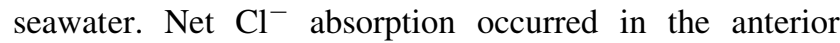
$\left(21 \mathrm{mmol} \mathrm{kg}^{-1}\right)$, mid $\left(4 \mathrm{mmol} \mathrm{kg}{ }^{-1}\right)$ and posterior intestinal sections ( $1 \mathrm{mmol} \mathrm{kg}^{-1}$ ) (Fig. 2b). Overall, $55 \mathrm{mmol}$ $\mathrm{kg}^{-1} \mathrm{Cl}^{-}$was added to the GI tract $\left(6.6 \mathrm{mmol} \mathrm{kg}^{-1}\right.$ from the diet, $46 \mathrm{mmol} \mathrm{kg}^{-1}$ from the ingested seawater, $1.9 \mathrm{mmol} \mathrm{kg}^{-1}$ total from the gastrointestinal tract). Approximately $54 \mathrm{mmol} \mathrm{kg}^{-1}$ was absorbed by the GI tract resulting in an average net $\mathrm{Cl}^{-}$absorption of $52 \mathrm{mmol} \mathrm{kg}^{-1}$. Combined with a total ingestion of $\sim 53 \mathrm{mmol} \mathrm{kg}{ }^{-1}, \mathrm{Cl}^{-}$ underwent a net assimilation of $98 \%$ (Fig. 2b), again the diet forming a small fraction.

$\mathrm{K}^{+}$underwent net absorption in all GI tract sections with the exception of a slight secretion into the anterior intestine and caecae at 4 and $8 \mathrm{~h}$ following feeding (Fig. 2c). The diet provided $3.4 \mathrm{mmol} \mathrm{K}^{+} \mathrm{kg}^{-1}$, while the ingested water provided $0.8 \mathrm{mmol} \mathrm{K}^{+} \mathrm{kg}^{-1}$. Additionally, a further $1.6 \mathrm{mmol} \mathrm{K} \mathrm{Kg}^{-1}$ was secreted by the anterior intestine and caecae providing additional $\mathrm{K}^{+}$for absorption. The mid intestine absorbed $1.4 \mathrm{mmol} \mathrm{kg}^{-1}$ while the posterior intestine absorbed $0.1 \mathrm{mmol} \mathrm{kg}^{-1}$ (Fig. 2c). On a net basis, $3.9 \mathrm{mmol} \mathrm{kg}^{-1}$ of $\mathrm{K}^{+}$was absorbed by the GI tract $\left(5.5 \mathrm{mmol} \mathrm{kg}^{-1}\right.$ total absorption, $1.6 \mathrm{mmol} \mathrm{kg} \mathrm{kg}^{-1}$ total secretion, Fig. 2c), indicating a net assimilation of $\sim 93 \%$ of the total $\mathrm{K}^{+}$consumed $\left(4.2 \mathrm{mmol} \mathrm{kg}{ }^{-1}\right)$, a majority of which was supplied by the diet (3.4 vs. $0.8 \mathrm{mmol} \mathrm{kg}^{-1}$ ).

The handling of $\mathrm{Ca}^{2+}$ by the oesophagus-stomach and anterior intestine and caecae was similar to that of $\mathrm{K}^{+}$ (Fig. 3a). However, the total amount of $\mathrm{Ca}^{2+}$ absorbed in mid intestine was twofold lower and more variable when compared to $\mathrm{K}^{+}$, and the posterior intestinal tract did not appear to exhibit net absorption or secretion of $\mathrm{Ca}^{2+}$ (Fig. 3a). Overall, the diet provided $6.3 \mathrm{mmol} \mathrm{kg}^{-1}$ of $\mathrm{Ca}^{2+}$, and the ingested water provided $0.9 \mathrm{mmol} \mathrm{kg}{ }^{-1}$. Secretion by the intestine comprised $1.4 \mathrm{mmol} \mathrm{kg}^{-1}$, creating a total addition of $\mathrm{Ca}^{2+}$ to the GI tract amounting to $8.6 \mathrm{mmol} \mathrm{kg}^{-1}$. In general, $4.5 \mathrm{mmol} \mathrm{kg}{ }^{-1}$ of $\mathrm{Ca}^{2+}$ was absorbed, mostly by the oesophagus-stomach. This 


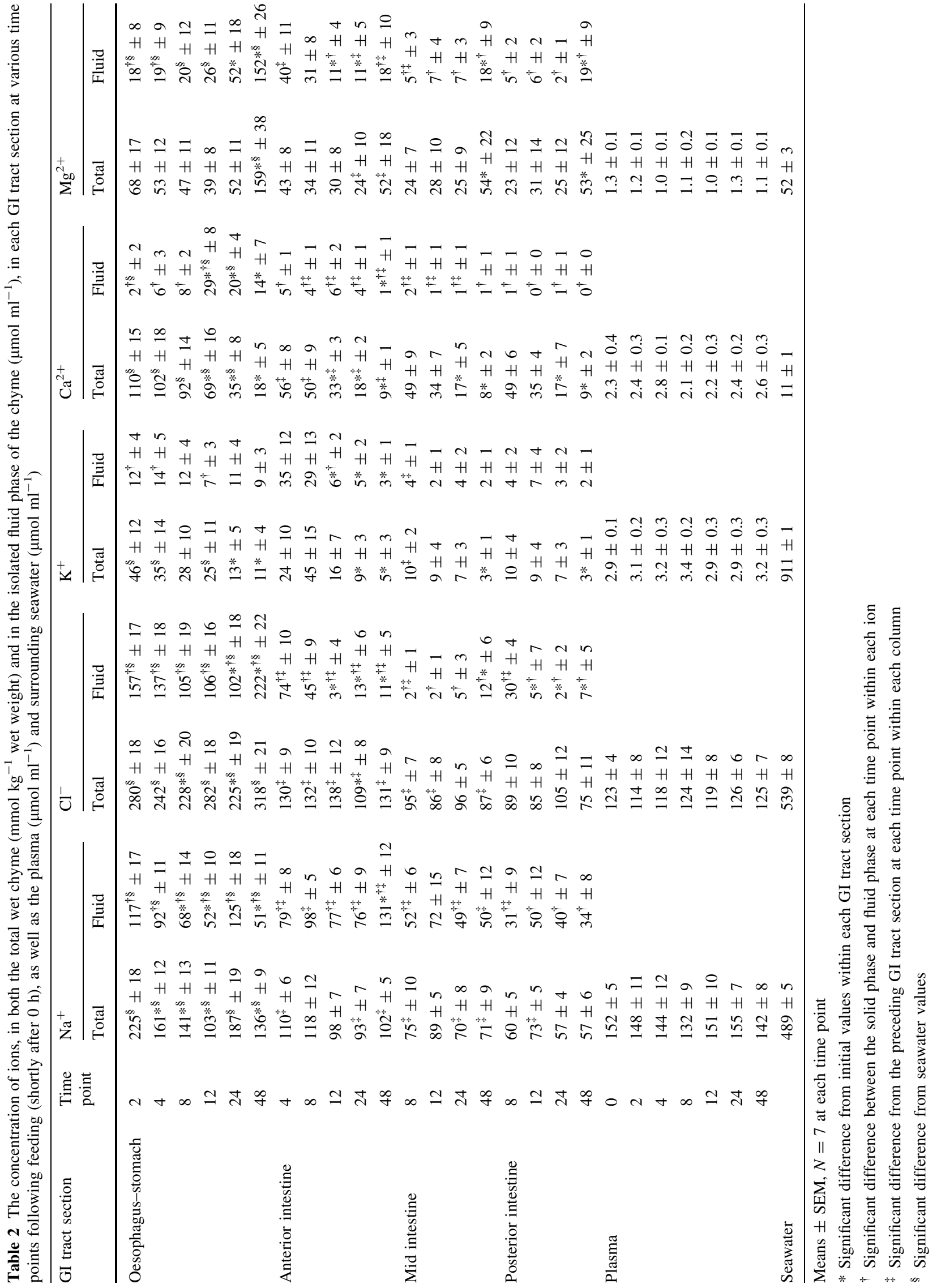



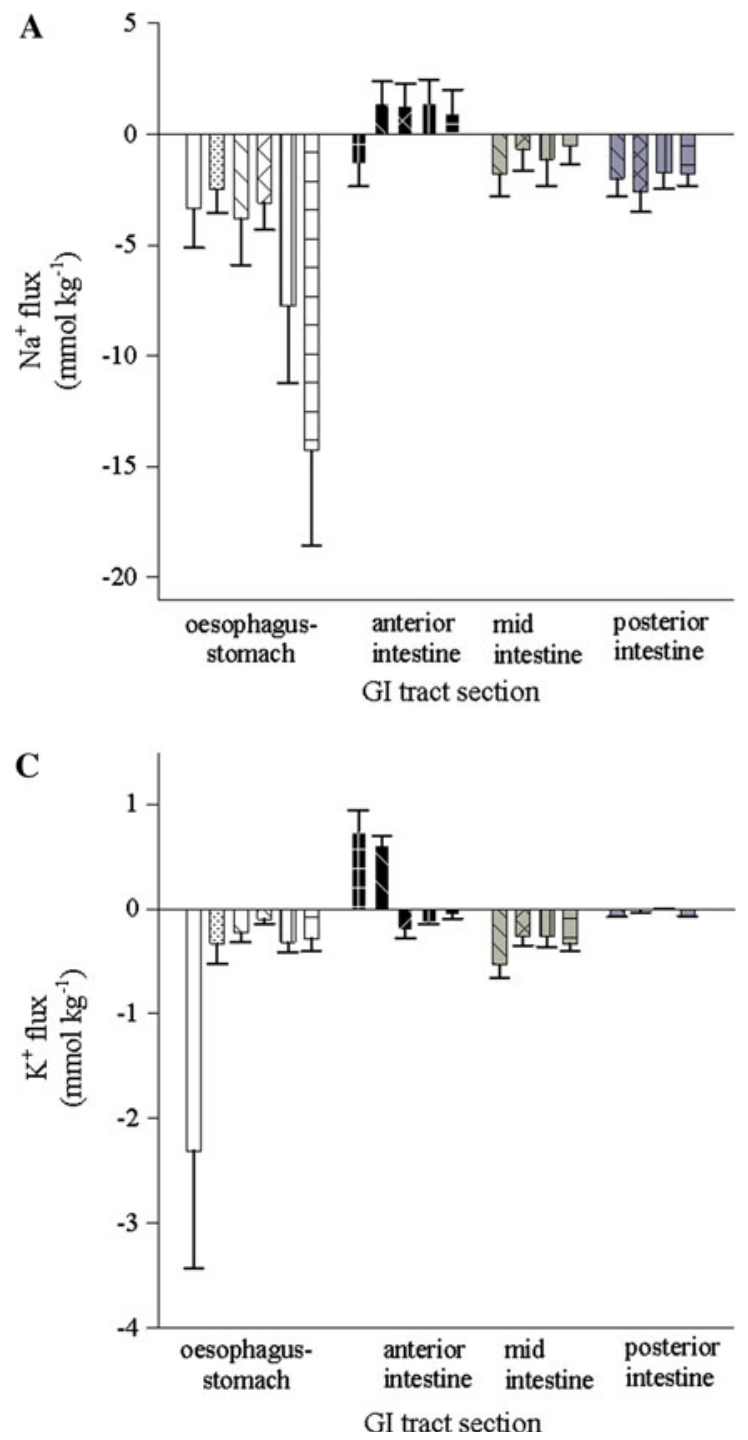

Fig. 2 Flux of (a) $\mathrm{Na}^{+}\left(\mathrm{mmol} \mathrm{kg}{ }^{-1}\right)$, (b) $\mathrm{Cl}^{-}\left(\mathrm{mmol} \mathrm{kg}{ }^{-1}\right)$, and (c) $\mathrm{K}^{+}\left(\mathrm{mmol} \mathrm{kg}^{-1}\right)$ into each GI tract section over time during the digestion of a single meal by seawater rainbow trout. Positive values indicate secretion while negative values indicate absorption. Feeding

combined with the secretion noted above resulted in a net assimilation of $3.1 \mathrm{mmol} \mathrm{kg}^{-1}$ or $43 \%$ of consumed $\mathrm{Ca}^{2+}$ (Fig. 3a). A large portion of both $\mathrm{K}^{+}$and $\mathrm{Ca}^{2+}$ absorbed were therefore supplied by the diet rather than by imbibed seawater, in contrast to $\mathrm{Na}^{+}$and $\mathrm{Cl}^{-}$.

The handling of $\mathrm{Mg}^{2+}$ appeared qualitatively similar to that of $\mathrm{Ca}^{2+}$, although the total secretion of $\mathrm{Mg}^{2+}$ into the anterior intestine and caecae was approximately four-fold greater than that of $\mathrm{Ca}^{2+}$ (Fig. 3b). Overall, $3.6 \mathrm{mmol} \mathrm{\textrm {Mg } ^ { 2 + }}$ $\mathrm{kg}^{-1}$ was ingested through the diet, while $4.5 \mathrm{mmol} \mathrm{kg}$ was ingested via the water, and $5.8 \mathrm{mmol} \mathrm{kg}^{-1}$ was secreted by the intestine, mostly the anterior section (Fig. 3b). This created $\mathrm{a} \mathrm{Mg}^{2+}$ load in the intestine of approximately $14 \mathrm{mmol} \mathrm{kg}{ }^{-1}$. The intestinal secretions of $\mathrm{Mg}^{2+}$ combined with a total absorption of $\sim 5.3 \mathrm{mmol} \mathrm{kg}^{-1}$, resulted in an
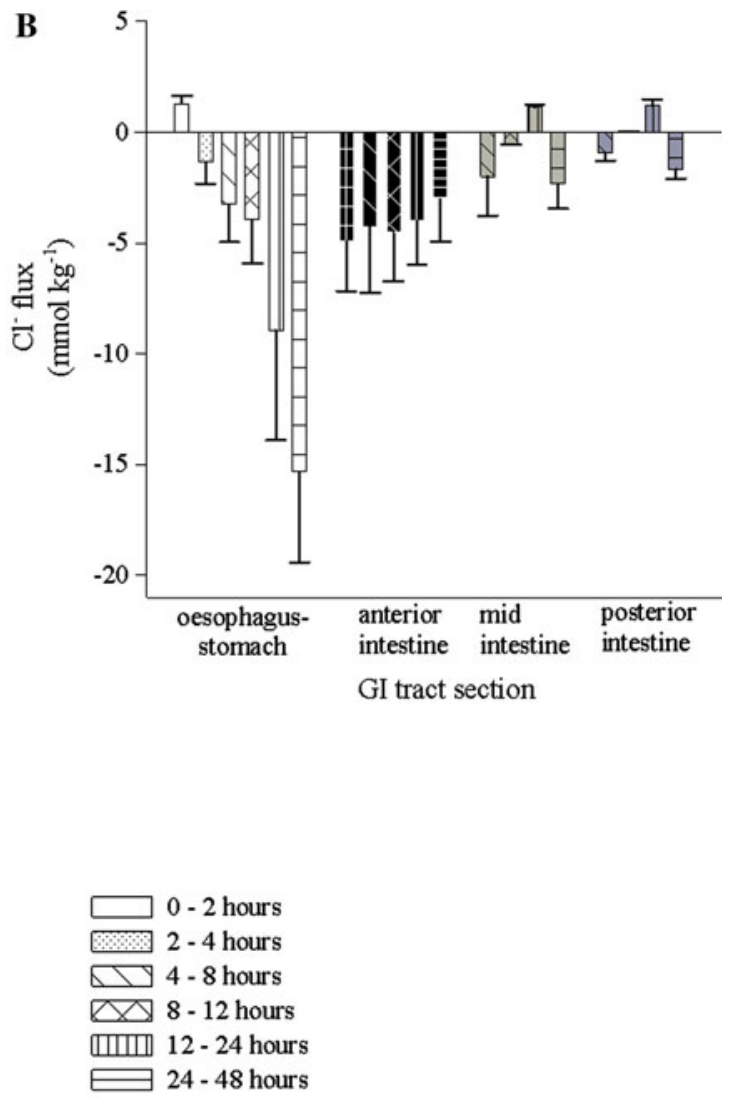

occurred immediately after $0 \mathrm{~h}$. Note that these are absolute fluxes over the specified time intervals, so individual statistical comparisons are not appropriate as intervals differ. Mean $\pm 1 \operatorname{SEM}(N=7)$

overall net loss of $\mathrm{Mg}^{2+}$ to the environment of $0.5 \mathrm{mmol} \mathrm{kg}^{-1}$ representing a minimal amount $(\sim 3 \%$ of the ingested load).

Feeding had no effect on the ionic composition of the plasma at any of the sampling times (Table 2). Overall, average values were: $\mathrm{Na}^{+}=147.5 \pm 3.2 ; \mathrm{Cl}^{-}=121.4 \pm$ $2.9 ; \mathrm{K}^{+}=3.1 \pm 0.14 ; \mathrm{Ca}^{2+}=2.4 \pm 0.15 ; \mathrm{Mg}^{2+}=1.1 \pm$ $0.10 \mu \mathrm{mol} \mathrm{ml}{ }^{-1}(N=49$; Table 2). Comparison of these values with corresponding ion concentrations in the fluid phase of the chyme (Table 2) reveals that $\mathrm{Na}^{+}$and $\mathrm{Cl}^{-}$ absorption occurred (Fig. 2a, b) despite increasingly steep concentration gradients opposing absorption of these ions, moving from the oesophagus-stomach to the posterior section of the tract, gradients which also tended to become greater with time after feeding. In contrast, concentration 
Fig. 3 Flux of (a) $\mathrm{Ca}^{2+}$ $\left(\mathrm{mmol} \mathrm{kg}{ }^{-1}\right)$ and (b) $\mathrm{Mg}^{2+}$ $\left(\mathrm{mmol} \mathrm{kg}{ }^{-1}\right)$ into each GI tract section over time during the digestion of a single meal by seawater rainbow trout. Positive values indicate secretion while negative values indicate absorption. Feeding occurred immediately after $0 \mathrm{~h}$. Note that these are absolute fluxes over the specified time intervals, so individual statistical comparisons are not appropriate as intervals differ.

Mean $\pm 1 \operatorname{SEM}(N=7)$
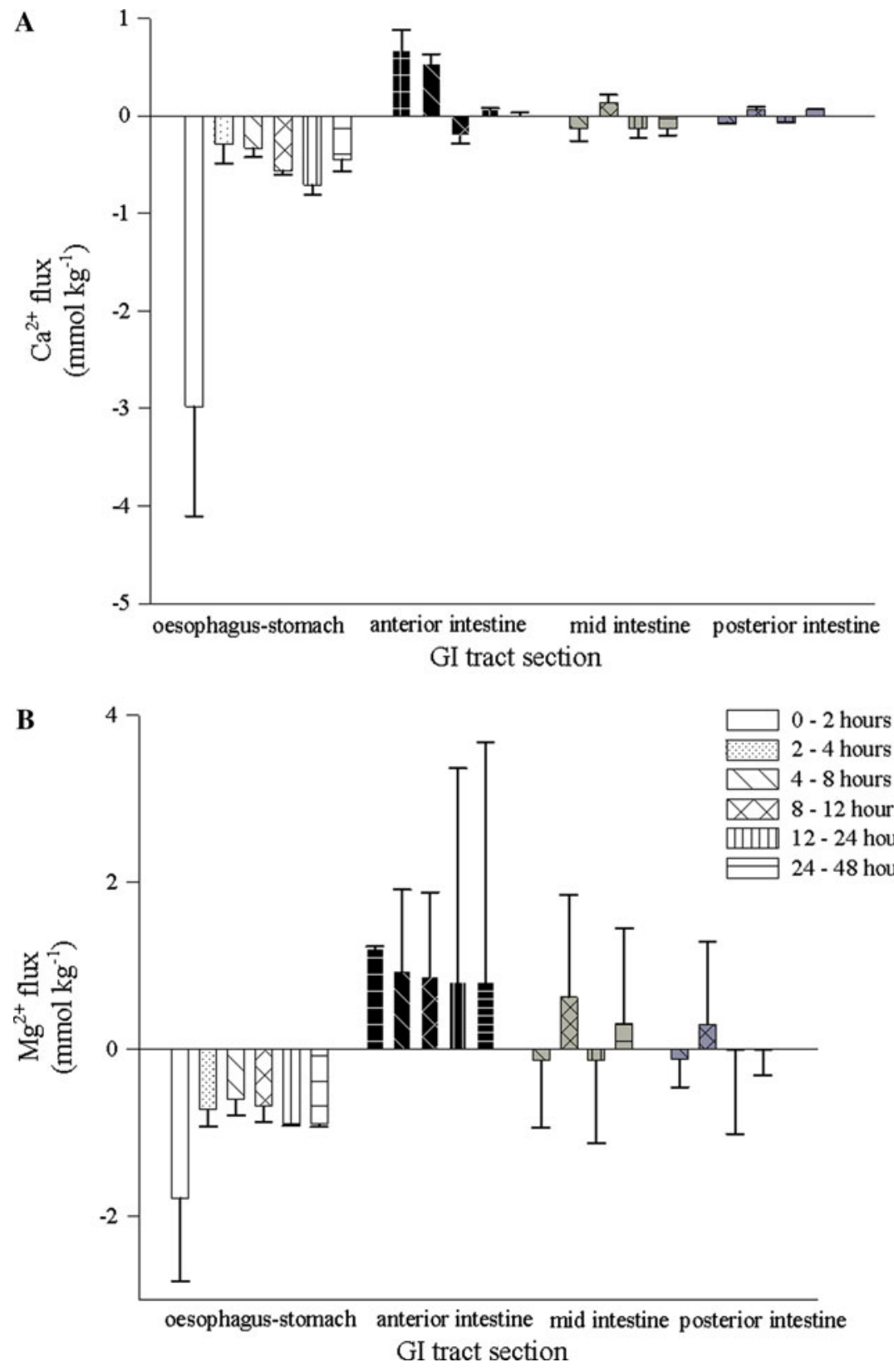

gradients from chyme fluid to plasma were initially in favour of $\mathrm{K}^{+}$absorption (Fig. 2c), but declined with both time and distance along the tract until approximate equilibrium was established (Table 2). For $\mathrm{Ca}^{2+}$, concentration gradients were only strongly in favour of absorption (Fig. 3a) in the gastric fluids during the second $24 \mathrm{~h}$ after ingestion of the meal; at other times and in all other sections of the tract, $\mathrm{Ca}^{2+}$ concentrations in chyme fluid were comparable to or below plasma concentrations (Table 2). For $\mathrm{Mg}^{2+}$, negligible net absorption occurred (Fig. 3b), despite concentration gradients favouring absorption at virtually all time points in all sections of the tract (Table 2).

The $\mathrm{pH}$ of the stomach chyme decreased during the $48 \mathrm{~h}$ digestive period, falling from an initial, unfed value of
$6.58 \pm 0.12(N=7)$ to a final value of $3.19 \pm 0.22$ $(N=7)$ by $48 \mathrm{~h}$ following the ingestion of a meal (Fig. 4). In contrast, there was no significant effect of feeding or time on intestinal $\mathrm{pH}$ within each section (Fig. 4), although $\mathrm{pH}$ did increase along the intestinal sections. Mean values were $7.69 \pm 0.2 \quad(N=49), 8.14 \pm 02 \quad(N=49)$, and $8.52 \pm 0.14(N=49)$ for the anterior, mid and posterior intestine, respectively.

\section{Discussion}

In contrast to previous studies wherein drinking rates increased following feeding (seawater Atlantic salmon; 
Fig. 4 The $\mathrm{pH}$ profile along the GI tract of seawater-acclimated rainbow trout in the stomach, anterior intestine and caecae, mid intestine, and posterior intestine. Arrows indicate time of arrival of chyme in each section. For both the posterior and mid intestine, this occurred at $8 \mathrm{~h}$. The vertical line indicates time of feeding. Time points that share letters are not significantly different

$(P>0.05)$. There were no significant effects of time on the $\mathrm{pH}$ of the intestinal samples. Mean \pm 1 SEM $(\mathrm{N}=7)$

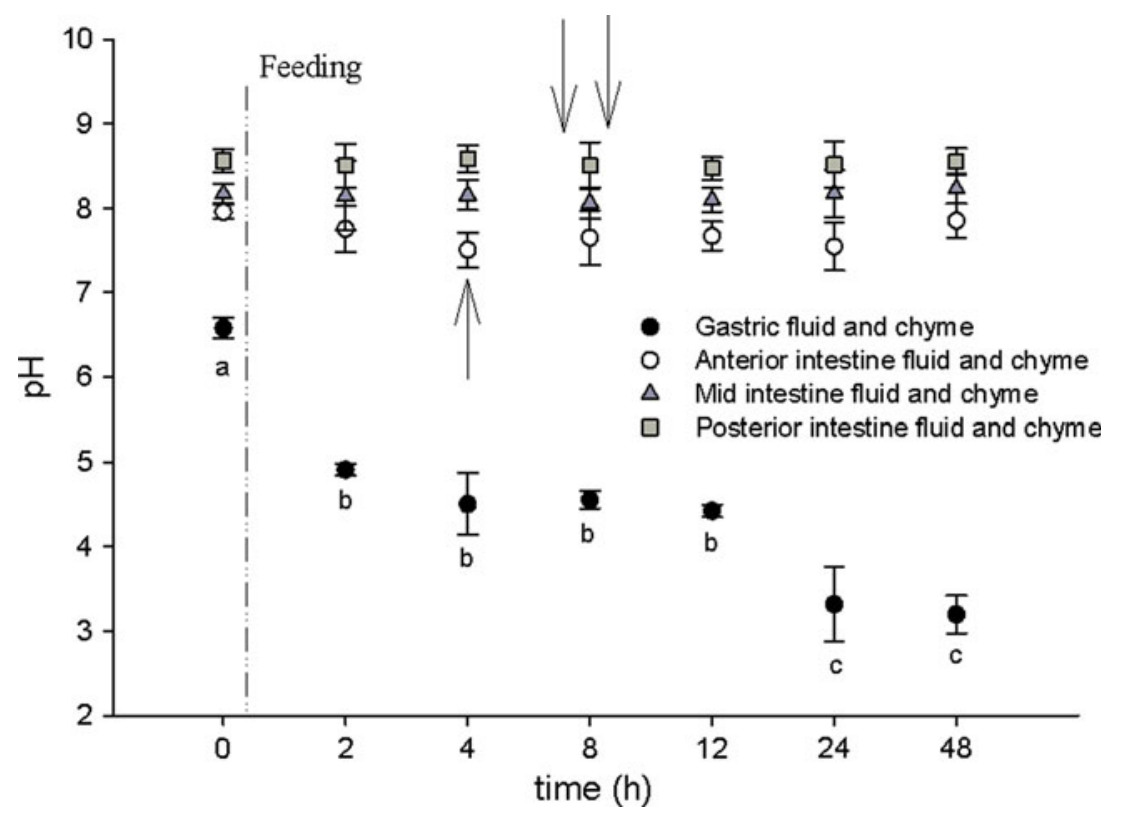

Usher et al. 1988; freshwater rainbow trout; Tytler et al. 1990; Kristiansen and Rankin 2001), feeding had no effect on the measured drinking rates in the current study. Additionally, feeding did not appear to result in a significant net secretion of endogenous water into the oesophagus-stomach during the secretion of $\mathrm{HCl}$ as the ratio of the concentration of PEG found in the stomach fluid of fed fish versus the concentration of PEG found in the external water was approximately $1(0.98 \pm 0.20, N=28)$, suggesting that there was little to no net secretion and/or absorption of endogenous fluid into the oesophagusstomach lumen, or that the rates and/or magnitude of secretion and absorption were closely matched. Quite possibly, fluid absorption in the oesophagus and gastric $\mathrm{HCl}$ secretion in the stomach were of generally similar magnitude, cancelling each other on a net basis, although the oesophagus is known to have low water permeability (Nagashima and Ando 1994). Hirano (1974) actually inhibited drinking in the seawater eel by distending the stomach with isotonic solutions of mannitol. Perhaps the size of the meal ingested can affect the drinking rate, with smaller meals increasing the amount of water imbibed, while larger meals reduce it. This hypothesis is supported by the slightly lower drinking rates reported in series 2 , where there was a slightly higher ration size as well. While the drinking rates in the present study may appear low compared to previously published rates for unfed seawater trout (e.g. Wilson et al. 1996; Shehadeh and Gordon 1969) and may relate to methodological differences, similar drinking rates have been observed in several other studies on fasted seawater-adapted rainbow trout (Perrott et al. 1992; Wilson et al. 1996; Webb and Wood 2000).
Although we hypothesized that feeding would result in greater net water assimilation along the GI tract, the results suggest the opposite. The net assimilation of water along the GI tract during feeding was only approximately $63 \%$ (Fig. 1) which is lower than the net assimilation of water reported in several other studies of unfed rainbow trout in seawater (Shehadeh and Gordon 1969, 80\%; Kristens and Skadhauge 1974, 85\% (theoretical); Wilson et al. 1996, $85 \%)$. The secretion of fluid into the anterior intestine and caecae $\left(\sim 7 \mathrm{ml} \mathrm{kg}^{-1}\right.$ over $48 \mathrm{~h}$ ) was an important component reducing the net absorption of water. Very probably, this fluid was mainly accounted for by bile secretions which could account for up to $\sim 87 \%$ of the fluid secreted, based on the most comprehensive data set available (Grosell et al. 2000). However, a note of caution is that these data were for freshwater trout. The remainder of fluid secreted may have been pancreatic secretions associated with digestion, however unlike in mammals, pancreatic tissue in teleosts is diffuse (Fange and Grove 1979) and determining the volume of fluid secreted by these cells would be difficult. Regardless, if these secretions are removed from the overall net balance, the assimilation of water along the GI tract is still at the low end of water assimilation values ( $\sim 67$ vs. 80-95\% in unfed fish). This combined with a stable drinking rate during feeding, suggests that digestion of a commercial pellet meal may create an osmotic challenge during feeding by reducing the amount of water assimilation by the intestine and by inducing endogenous water loss through biliary and pancreatic secretions. Chyme osmolality was not measured in the present study; however, Bucking and Wood (2006a) reported that when a feed of similar composition was ingested by freshwater rainbow trout, the osmolality of the 
fluid phase of the chyme was initially three times that of plasma levels, and remained significantly higher than plasma osmolality in all sections of the gut during the entire $48 \mathrm{~h}$ post-feeding period. This effect was not completely accounted for by measured inorganic ions in the chyme fluid (Bucking and Wood 2006b, 2007) and likely reflected an important contribution from organic osmolytes mobilized during digestion of this "dry" diet. Similarly, in the seawater gulf toadfish fed two natural diets, chyme osmolality consistently exceeded plasma osmolality, a difference which again was only partially explained by measured inorganic electrolyte concentrations (Taylor and Grosell 2006).

Another factor reducing water absorption in fed trout may be the presence of soluble fibers incorporated into the feed mixtures which are believed to increase the water holding capacity of the chyme (Choct and Annison 1990), thereby reducing that amount of water available for absorption. Mucus, produced mainly by goblet cells releasing glycoproteins (mucins) has significant effects on water diffusion which are correlated with the concentration of mucins within the mucus itself (Shephard 1981, 1994). If feeding were to increase the amount of mucus produced, or the amount of mucins within the mucus, this could be another factor reducing water absorption.

Another possibility to explain the decrease in water assimilation along the GI tract of fed fish is that the absorption of nutrients may result in a decreased amount of $\mathrm{H}^{+}$available for the conversion of $\mathrm{HCO}_{3}{ }^{-}$into $\mathrm{CO}_{2}$ in the intestinal lumen. This conversion of $\mathrm{HCO}_{3}{ }^{-}$into $\mathrm{CO}_{2}$ in the intestinal lumen is important to drive intestinal water uptake (reviewed by Grosell et al. 2009b) and a reduction in luminal protons may decrease water uptake. For example, the absorption of di- and tri-peptides via a $\mathrm{H}^{+}$cotransporter (PEPT1; reviewed by Daniel 2004; Meredith 2009) found along the piscine intestine (Amberg et al. 2008; Verri et al. 2003; Terova et al. 2009) may sequester $\mathrm{H}^{+}$away from the mechanisms of water transport. Clearly, multiple complicated processes may be at work here and require additional investigation.

Interestingly, the net assimilation of $\mathrm{Na}^{+}, \mathrm{Cl}^{-}$and $\mathrm{K}^{+}$in seawater (86-98\%; Fig. 2) was similar to assimilation efficiencies in unfed rainbow trout (90-95\%; Shehadeh and Gordon 1969; Kristens and Skadhauge 1974; Dabrowski et al. 1986). As net water movement is believed to be linked to monovalent ion movement, the decreased water assimilation was apparently not caused by a decrease in ion assimilation. When the net absorbed fluid ( $\left.45 \mathrm{ml} \mathrm{kg}^{-1}\right)$ and the net absorbed ions $\left(\mathrm{Na}^{+}=43 ; \mathrm{Cl}^{-}=52 ; \mathrm{K}^{+}=3.9\right.$; $\mathrm{Ca}^{2+}=3.1 \mathrm{mmol} \mathrm{kg}^{-1}$, there is no net $\mathrm{Mg}^{2+}$ absorption) are used to calculate the ion concentrations in the absorbed fluid, the results are surprisingly hypertonic relative to the plasma $\left(\mathrm{Na}^{+}=956 ; \mathrm{Cl}^{-}=1156 ; \mathrm{K}^{+}=87\right.$;
$\left.\mathrm{Ca}^{2+}=69 \mathrm{mmol} \mathrm{l}^{-1}\right)$. This finding supports the demonstration that marine teleosts absorb a hypertonic solution on a net basis across their intestine (Grosell 2006; Grosell and Taylor 2007). Furthermore, by comparison to the calculated absorbate concentrations for fasted fish (Grosell 2006), the current study suggests that the absorbate concentrations may be even more elevated when teleosts are absorbing a meal. However, it is important to note that the current experimental design reveals the net movement of water and ions at each time point, but is unable to distinguish between the individual contributions of absorption and secretion.

While $86-98 \%$ of the ingested $\mathrm{Na}^{+}$and $\mathrm{Cl}^{-}$ions were absorbed by the gastrointestinal tract, the majority of these ions were sequestered from the imbibed seawater and the diet provided only $15-20 \%$ of the total ions ingested. In contrast, and as predicted, $\mathrm{K}^{+}$and $\mathrm{Ca}^{2+}$ were assimilated above levels that could have been provided by imbibed seawater alone (Figs. 2c, 3a), suggesting that seawater rainbow trout may utilize the diet for $\mathrm{K}^{+}$and $\mathrm{Ca}^{2+}$. Interestingly, the net absorption of ingested $\mathrm{Ca}^{2+}$ (43\% net assimilation) in the current study was quantitatively similar to previous studies on unfed marine fish (e.g. 35\% net assimilation in unfed trout, Shehadeh and Gordon 1969; $31 \%$ in unfed cod, Fletcher 1978), despite the ingestion of considerably larger $\mathrm{Ca}^{2+}$ loads in the meal. Absorption of $\mathrm{Ca}^{2+}$ from the diet is surprising as seawater trout face an excess of $\mathrm{Ca}^{2+}$ in the water compared to bodily concentrations. $\mathrm{Mg}^{2+}$ is also in great excess in seawater relative to teleost body fluids. In contrast to $\mathrm{Ca}^{2+}$, the negligible (slightly negative) net $\mathrm{Mg}^{2+}$ absorption efficiency was lower than reported in fasted seawater trout (41-48\%; Shehadeh and Gordon 1969; Wilson et al. 1996), and in fasted seawater flounder (16\%; Hickman 1968), so it is possible that feeding actually inhibits $\mathrm{Mg}^{2+}$ absorption. Perhaps the increased $\mathrm{HCO}_{3}{ }^{-}$secretion (Bucking et al. 2009) increases magnesium carbonate precipitation in the tract, although only a minor fraction of intestinal magnesium is found as a precipitate.

Quantitative comparisons of ion transport and assimilation from the diet are difficult to make with other feeding studies, due to methodological differences (i.e. a lack of an inert marker for examining net transport of ions in all previous studies). However qualitative observations can be made. Generally, monovalent ions are absorbed along the GI tract in postprandial marine fish (dogfish shark; Wood et al. 2007a, b; gulf toadfish, Taylor and Grosell 2006). Additionally, $\mathrm{Mg}^{2+}$ is excluded from absorption along the intestinal tract, as is $\mathrm{Ca}^{2+}$ to a lesser extent. The oesophagus-stomach however, has shown to be an impressive site of absorption for both $\mathrm{Ca}^{2+}$ and $\mathrm{Mg}^{2+}$.

The diet fed in this study was a commercial fish feed consisting of ground fish meal and various other fillers 
(salts, ash, carbohydrates, etc.) and contained $\mathrm{K}^{+}$levels ( $99 \mu \mathrm{mol} \mathrm{g}^{-1}$ wet weight) slightly above those found in pure fish meal diets (e.g. sardines $=70 \mu \mathrm{mol} \mathrm{g}^{-1}$ wet weight; squid $=60 \mu \mathrm{mol} \mathrm{g}^{-1}$ wet weight; Taylor and Grosell 2006). In contrast, $\mathrm{Ca}^{2+}$ levels were $186 \mu \mathrm{mol} \mathrm{g}$ wet weight versus sardines $=400 \mu \mathrm{mol} \mathrm{g}^{-1}$, squid $=$ $2 \mu \mathrm{mol} \mathrm{g}^{-1}$ (Taylor and Grosell 2006). Clearly, food ingested in the wild will vary in terms of overall ionic content, however for the majority of fish that consume piscivorous diets, the diet will act as a source of $\mathrm{K}^{+}$and $\mathrm{Ca}^{2+}$ above that which is absorbed through ingested seawater. Interestingly, the protein and carbohydrate composition of the diet can also alter the bioavailability of minerals, in addition to that of water, through increased electrostatic binding or trapping of minerals to newly revealed free anionic binding sites as protein and carbohydrate digestion proceeds (James et al. 1978; Singh and Krikorian 1982; Liener 1994).

No disturbances in plasma ion composition were observed throughout the present experiment. In fact plasma ion concentrations appear to be tightly regulated after feeding in both seawater (present study, Taylor and Grosell 2006) and freshwater fish, where only brief transient changes occurred in plasma $\mathrm{Na}^{+}, \mathrm{Ca}^{2+}$ and $\mathrm{Mg}^{2+}$ concentrations (Bucking and Wood 2006b, 2007) despite large scale absorption of the majority of ions. Therefore, gill and renal effluxes of $\mathrm{Na}^{+}, \mathrm{Cl}^{-}, \mathrm{Ca}^{2+}$, and $\mathrm{K}^{+}$should increase in seawater fish following feeding, however to our knowledge this phenomenon has only been observed in freshwater fish (Smith et al. 1995).

\section{Comparisons with freshwater rainbow trout}

While this study is one of only a handful to address the role of feeding in ionoregulation in seawater fish, recent efforts have promoted our understanding of the consequences of feeding in freshwater fish. Therefore it is of interest to compare the present results on seawater-acclimated rainbow trout to those obtained from freshwater-acclimated rainbow trout under similar experimental conditions (Bucking and Wood 2006a, b, 2007, 2009). There were substantial differences in the initial $\mathrm{pH}$ of the stomach fluids prior to feeding (freshwater fish gastric $\mathrm{pH} 2.7$, Bucking and Wood 2009; seawater fish gastric pH 6.6, present study); the higher gastric $\mathrm{pH}$ in unfed seawater trout presumably reflecting the buffering action of the seawater ingested in drinking. Following feeding there were surprisingly small differences in $\mathrm{pH}$ profiles in the stomach and in the various intestinal sections, despite the higher intestinal $\mathrm{HCO}_{3}{ }^{-}$secretion rates reported in seawater trout (Bucking et al. 2009). Feeding and digestion were associated with significant water losses to the GI tract in freshwater rainbow trout (Bucking and Wood 2006a); a total of approximately $17 \mathrm{ml} \mathrm{kg}^{-1}$ was lost to the GI tract, $\sim 9 \mathrm{ml} \mathrm{kg}^{-1}$ of which was thought to be bile and pancreatic secretions. In freshwater this would help to balance the diffusive water influx to which these fish are continually subjected. A similar water loss via bile and pancreatic secretions to the anterior intestine and caecae in seawater fish was observed (Fig. 1; $7 \mathrm{ml}^{-1} \mathrm{~kg}^{-1}$ secreted into the intestine). After incorporating these secretions into net intestinal water balance, the fluid loss at the intestine of fed seawater-acclimated trout amounts to an approximate "rectal fluid" loss of approximately $0.6 \mathrm{ml} \mathrm{kg} \mathrm{k}^{-1} \mathrm{~h}^{-1}$, whereas unfed seawater-acclimated rainbow trout exhibit a measured rectal fluid loss of approximately $0.48 \mathrm{ml} \mathrm{kg}^{-1} \mathrm{~h}^{-1}$ (Wilson et al. 1996).

In freshwater trout, feeding has been associated with the absorption of significant and beneficial quantities of dietary ions (Fig. 5), which would help animals to maintain body
Fig. 5 The net assimilation (\%) of dietary ions in freshwater and seawater. Freshwater values were assembled from Bucking and Wood (2006b, 2007). Positive values indicate net assimilation, while negative values indicate net loss of ions to the environment

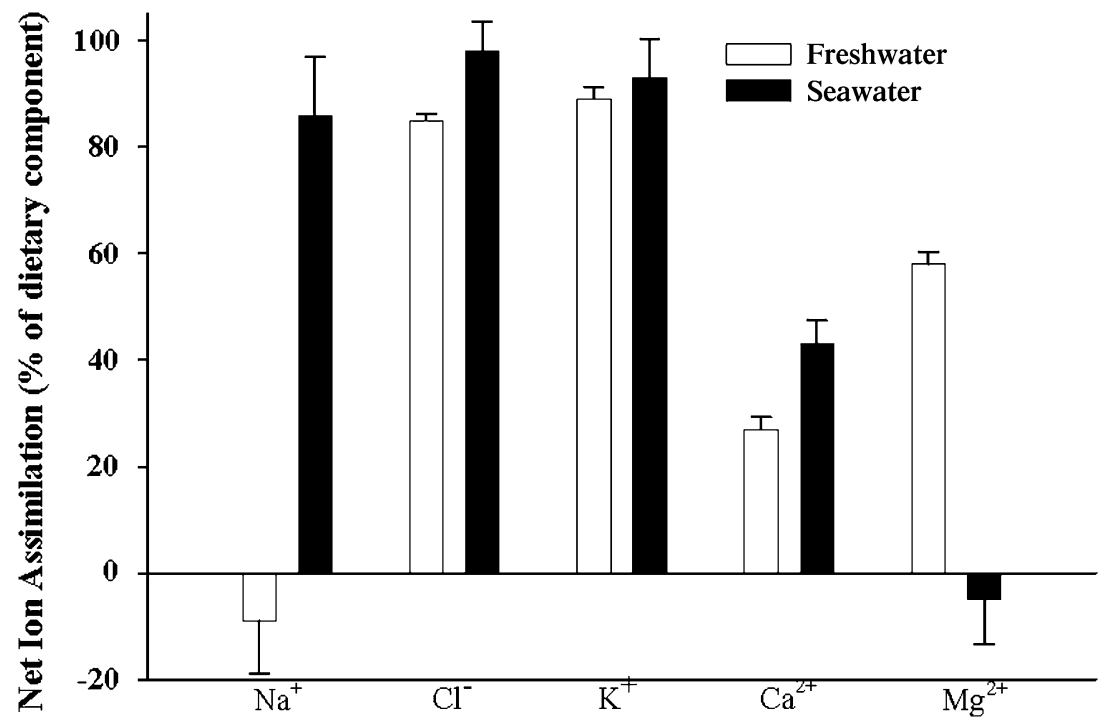



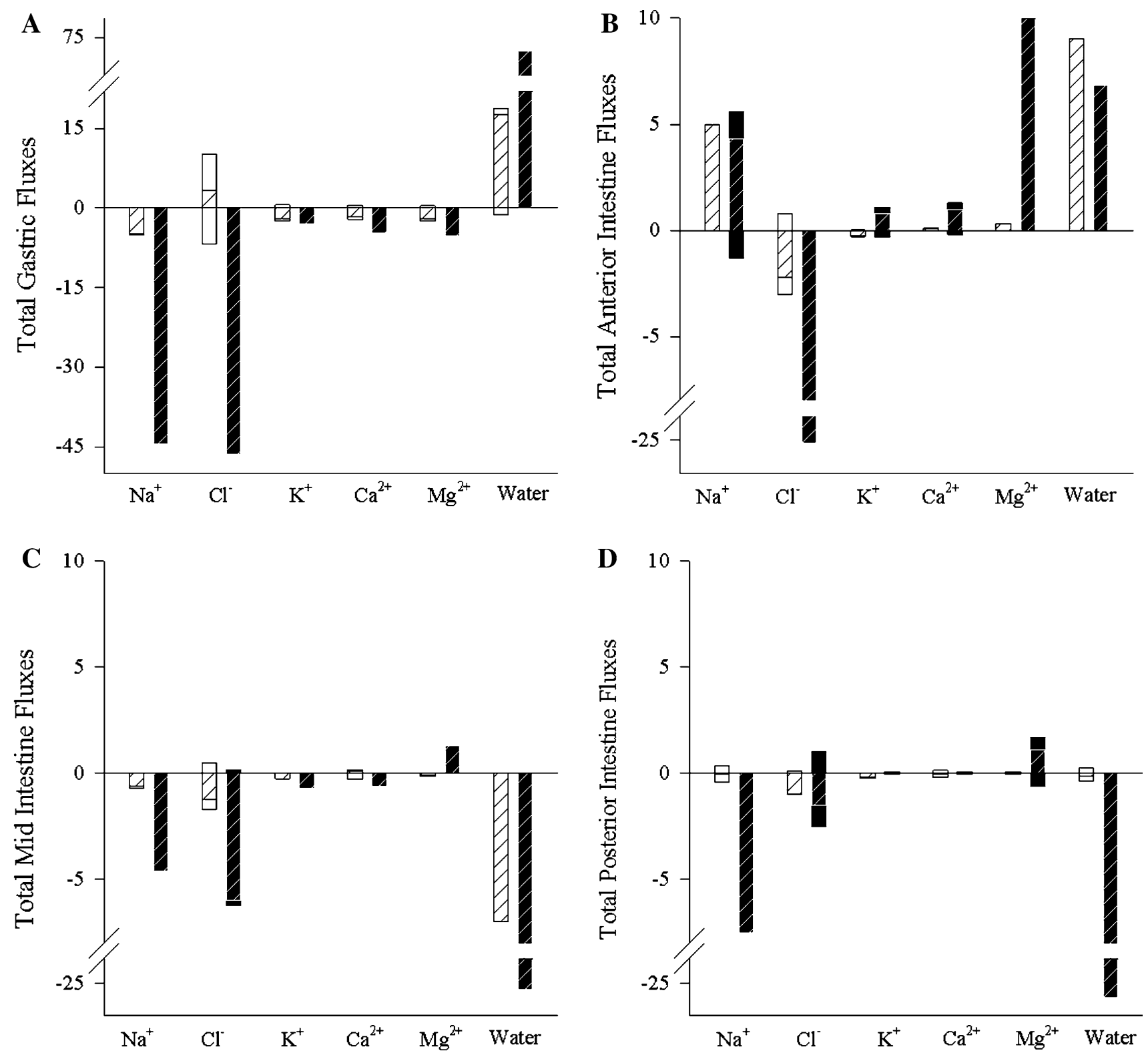

Fig. 6 Comparison of total water $\left(\mathrm{ml} \mathrm{kg}^{-1}\right)$ and ion transport $\left(\mathrm{mmol} \mathrm{kg}{ }^{-1}\right)$ during digestion in each gut compartment [(a) oesophagus-stomach, (b) Anterior intestine and caecae, (c) mid intestine, (d) posterior intestine] of freshwater rainbow trout (white bars, data

salt levels in the face of diffusive loss (Bucking and Wood $2006 \mathrm{~b}, 2007)$. The only exception is $\mathrm{Na}^{+}$which was lost to the environment on a net basis (Fig. 5; Bucking and Wood 2006b). Therefore, due to low drinking rates and even lower ion concentrations in the surrounding water, the diet provides almost all of the enterically absorbed ions in freshwater trout. These results reflect the beneficial consequences of feeding and digestion in fresh water which tend to counteract the osmotic gain and ion loss faced in hyposmotic environments. In seawater-acclimated trout the majority of the sequestered $\mathrm{K}^{+}$and $\mathrm{Ca}^{2+}$ were taken up from the diet (Fig. 5), while $\mathrm{Na}^{+}$

from Bucking and Wood 2006a, b, 2007) and seawater rainbow trout (black bars). Positive values indicate total secretory fluxes, negative values indicate total absorptive fluxes. Hatched bars indicate net fluxes (difference between secretory and absorptive fluxes)

and $\mathrm{Cl}^{-}$in the feed provided only $15-20 \%$ of the ingested ions, and $\mathrm{Mg}^{2+}$ was not taken up on a net basis from either the food or seawater. While the resultant net intestinal loss of $\mathrm{Na}^{+}$ was a challenge facing freshwater-acclimated trout, the secretion of these ions into the anterior intestine and caecae and their subsequent loss to the feces (as well as their loss in the formation of new bile and pancreatic fluids), may reflect an ionoregulatory benefit to digestion in seawater-acclimated trout.

When comparing the ionic regulatory ability of specific sections of the tract (Fig. 6), with the exception of $\mathrm{Cl}^{-}$ 
regulation, the stomach handled water and ions in a fairly similar manner in both freshwater and seawater in terms of the directionality of net fluxes. In freshwater-acclimated fish there was a noticeable secretion of $\mathrm{Cl}^{-}$into the gastric lumen presumably in the form of $\mathrm{HCl}$ for the purposes of digestion, whereas secretion of $\mathrm{HCl}$ was masked in the seawater-acclimated trout by the addition of external $\mathrm{Cl}^{-}$ during drinking events. However, the secretion of $\mathrm{HCl}$ was evident by the decreasing $\mathrm{pH}$ of the gastric lumen. Additionally, the magnitudes of the $\mathrm{Na}^{+}$and water fluxes were much greater for seawater fish than for freshwater fish; note in particular the much higher $\mathrm{Na}^{+}$and water absorption in the mid and posterior intestines of seawater trout (approximately 5-25 times larger). In the anterior intestine and caecae the net absorption of $\mathrm{Cl}^{-}$and secretion of $\mathrm{Mg}^{2+}$ was much larger in seawater trout as well. In contrast, $\mathrm{K}^{+}$ was absorbed on a net overall basis by the anterior intestine and caecae by fish acclimated to freshwater, while in seawater it was secreted.

\section{Summary}

The digestion of a commercial meal by seawater-acclimated rainbow trout resulted in decreased water assimilation by the intestine when compared to previously published values for unfed trout. The complicated milieu of the intestine during digestion along with the many physiological processes that occur create many potential avenues to explore for determining the cause of this reduction in water assimilation. The diet also provided significant amounts of $\mathrm{K}^{+}$and $\mathrm{Ca}^{2+}$ that were assimilated during digestion, despite seawater-acclimated trout facing a high level of $\mathrm{Ca}^{2+}$ in the water. $\mathrm{Na}^{+}, \mathrm{Cl}^{-}$, and $\mathrm{Mg}^{2+}$ in the food (also in excess in seawater) were either swamped out by imbibed seawater concentrations $\left(\mathrm{Na}^{+}\right.$and $\left.\mathrm{Cl}^{-}\right)$or negligibly handled by the GI tract $\left(\mathrm{Mg}^{2+}\right)$. This study highlights the need for further investigation into the effect of feeding and digestion on intestinal function in fish.

Acknowledgments We are grateful to the staff of the Robertson Creek Hatchery for the supply of steelhead trout, and to the staff of the Bamfield Marine Sciences Centre for their assistance, particularly the Research Coordinator, Dr. Bruce Cameron. Two anonymous reviewers provided constructive comments. Funded by an NSERC Discovery Grant to C.M.W., who is supported by the Canada Research Chair Program, and an NSF grant (IBN\#0313765) to I.J.M., C.B and J.L.F. were supported by NSERC Canada Graduate Scholarships.

\section{References}

Amberg JJ, Myr C, Kamisaka Y, Jordal AEO, Rust MB, Hardy RW, Koedijk R, Ronnestad I (2008) Expression of the oligopeptide transporter, PepT1, in larval Atlantic cod (Gadus morhua). Comp Biochem Physiol B 150:177-182
Ando M, Mukuda T, Kozaka T (2003) Water metabolism in the eel acclimated to sea water: from mouth to intestine. Comp Biochem Physiol B 136:621-633

Bucking C, Wood CM (2006a) Water dynamics in the digestive tract of the freshwater rainbow trout during the processing of a single meal. J Exp Biol 209:1883-1893

Bucking C, Wood CM (2006b) Gastrointestinal processing of $\mathrm{Na}^{+}$, $\mathrm{Cl}^{-}$, and $\mathrm{K}^{+}$during digestion: implications for homeostatic balance in freshwater rainbow trout. Am J Physiol 291:R1764R1772

Bucking C, Wood CM (2007) Gastrointestinal transport of $\mathrm{Ca}^{2+}$ and $\mathrm{Mg}^{2+}$ during the digestion of a single meal in the freshwater rainbow trout. J Comp Physiol B 177:349-360

Bucking C, Wood CM (2008) The alkaline tide and ammonia excretion after voluntary feeding in freshwater rainbow trout. J Exp Biol 211:2533-2541

Bucking C, Wood CM (2009) The effect of postprandial changes in $\mathrm{pH}$ along the gastrointestinal tract on the distribution of ions between the solid and fluid phases of chyme in rainbow trout. Aquac Nutr 15:282-296

Bucking C, Fitzpatrick JL, Nadella SR, Wood CM (2009) Postprandial metabolic alkalosis in the seawater-acclimated tout: the alkaline tide comes in. J Exp Biol 212:2159-2166

Buxton TB, Crockett JK, Moore WL, Moore WL, Rissing JP (1979) Protein precipitation by acetone for the analysis of polyethyleneglycol in intestinal perfusion fluid. Gastroenterology 76:820-824

Choct M, Annison G (1990) Antinutritive activity of wheat pentosans in broiler diets. Br Poult Sci 31:811-821

Dabrowski K, Leray C, Nonnotte G, Colin DA (1986) Protein digestions and ion concentrations in rainbow trout (Salmo gairdneri Rich) digestive tract in sea- and fresh-water. Comp Biochem Physiol A Mol Integr Physiol 83:27-39

Daniel H (2004) Molecular and integrative physiology of intestinal peptide transport. Ann Rev Physiol 66:361-384

Fange R, Grove D (1979) Digestion. In: Hoar WS, Randall DJ, Brett JR (eds) Fish physiology, vol 8. Academic Press, New York, pp $161-260$

Fletcher CR (1978) Osmotic and ionic regulation in cod (GadusCallarias L) 1. Water-balance. J Comp Physiol 124:149-155

Grosell M (2006) Intestinal anion exchange in marine fish osmoregulation. J Exp Biol 209:2813-2827

Grosell M, Taylor JR (2007) Intestinal anion exchange in teleost water balance. Comp Biochem Physiol 148:14-22

Grosell M, O'Donnell MJ, Wood CM (2000) Hepatic versus gallbladder bile composition: in vivo transport physiology of the gallbladder in rainbow trout. Am J Physiol 278:R1674-R1684

Grosell M, Wood CM, Wilson RW, Bury NR, Hogstrand C, Rankin C, Jensen FB (2005) Bicarbonate secretion plays a role in chloride and water absorption of the European flounder intestine. Am J Physiol 288:R936-R946

Grosell M, Genz J, Taylor JR, Perry SF, Gilmour KM (2009a) The involvement of $\mathrm{H}^{+}$-ATPase and carbonic anhydrase in intestinal $\mathrm{HCO}_{3}{ }^{-}$secretion in seawater-acclimated rainbow trout. J Exp Biol 212:1940-1948

Grosell M, Mager EM, Williams C, Taylor JR (2009b) High rates of $\mathrm{HCO}_{3}{ }^{-}$secretion and $\mathrm{Cl}^{-}$absorption against adverse gradients in the marine teleost intestine: the involvement of an electrogenic anion exchanger and $\mathrm{H}^{+}$-pump metabolon? J Exp Biol 212:1684-1696

Hickman CP (1968) Ingestion intestinal absorption and elimination of seawater and salts in southern flounder Paralichthys lethostigma. Can J Zool 46:457-466

Hirano T (1974) Some factors regulating water intake by the eel, Anguilla japonica. J Exp Biol 61:737-747

James WPT, Branch WJ, Southgate DAT (1978) Calcium binding by dietary fiber. Lancet 8065:638-639 
Kirsch R, Meister MF (1982) Progressive processing of ingested water in the gut of sea-water teleosts. J Exp Biol 98:67-81

Kristens K, Skadhauge E (1974) Flow along gut and intestinal absorption of salt and water in euryhaline teleosts-theoretical analysis. J Exp Biol 60:557-566

Kristiansen HR, Rankin JC (2001) Discrimination between endogenous and exogenous water sources in juvenile rainbow trout fed extruded dry feed. Aquating Living Res 14:359-366

Liener IE (1994) Implications of antinutritional components in soybean foods. Crit Rev Food Sci Nutr 34:31-67

Loo DD, Zeuthen T, Chandy G, Wright EM (1996) Cotransport of water by the $\mathrm{Na}^{+} /$glucose cotransporter. Proc Natl Acad Sci 93:13367-13370

Malawer SJ, Powell DW (1967) An improved turbidimetric analysis of polyethylene glycol utilizing an emulsifier. Gastroenterology 53:250-256

Meredith D (2009) The mammalian proton-coupled peptide cotransporter PepT1: sitting on the transporter-channel fence? Philos Trans R Soc B 364:203-207

Naftalin RJ (2008) Osmotic water transport with glucose in GLUT2 and SGLT. Biophys J 94:3912-3923

Nagashima K, Ando M (1994) Characterization of esophageal desalination in the seawater eel, Anguilla-japonica. J Comp Physiol 164:47-54

Niv Y, Fraser GM (2002) The alkaline tide phenomenon. J Clin Gastroenterol 35:5-8

Perrott MN, Grierson N, Hazon N, Balment RJ (1992) Drinking behavior in sea water and fresh water teleosts: the role of the renin-angiotensin system. Fish Physiol Biochem 10:161-168

Shehadeh ZH, Gordon MS (1969) The role of intestine in salinity adaptation of rainbow trout Salmo Gairdneri. Comp Biochem Physiol 30:397-418

Shephard KL (1981) The influence of mucus on the diffusion of water across fish epidermis. Physiol Zool 54:224-229

Shephard KL (1994) Functions for fish mucus. Rev Fish Biol Fish 4:401-429

Singh M, Krikorian AD (1982) Inhibition of trypsin activity in vitro by phytate. J Agric Food Chem 30:799-800

Smith N, Eddy F, Talbot C (1995) Effect of dietary salt load on transepithelial $\mathrm{Na}^{+}$exchange in freshwater rainbow trout (Oncorhynchus mykiss). J Exp Biol 198:2359-2364

Taylor JR, Grosell M (2006) Feeding and osmoregulation: dual function of the marine teleost intestine. J Exp Biol 209:2939-2951
Taylor JR, Grosell M (2010) The intestinal response to feeding in seawater gulf toadfish, Opsanus beta, includes elevated base secretion and increased epithelial oxygen consumption. J Exp Biol 212:3873-3881

Taylor JR, Whittamore JM, Wilson RW, Grosell M (2007) Postprandial acid-base balance and ion regulation in freshwater and seawater-acclimated European flounder, Platichthys flesus. J Comp Physiol B 177:597-608

Terova G, Cora S, Verri T, Rimoldi S, Bernardini G, Saroglia M (2009) Impact of feed availability on PepT1 mRNA expression levels in sea bass (Dicentrarchus labrax). Aquaculture 294:288 299

Tytler P, Tatner M, Findlay C (1990) The ontogeny of drinking in the rainbow trout, Oncorhynchus mykiss (Walbaum). J Fish Biol 36:867-875

Usher ML, Talbot C, Eddy FB (1988) Drinking in Atlantic salmon smolts transferred to seawater and the relationship between drinking and feeding. Aquaculture 73:237-246

Verri T, Kottra G, Romano A, Tiso N, Peric M, Maffia M, Boll M, Argenton F, Daniel H, Storelli C (2003) Molecular and functional characterisation of the zebrafish (Danio rerio) PEPT1-type peptide transporter. FEBS Lett 549:115-122

Webb NA, Wood CM (2000) Bioaccumulation and distribution of silver in four marine teleosts and two marine elasmobranchs: influence of exposure duration, concentration, and salinity. Aquat Toxicol 49:111-129

Wilson RW, Grosell M (2003) Intestinal bicarbonate secretion in marine teleost fish-source of bicarbonate, $\mathrm{pH}$ sensitivity, and consequences for whole animal acid-base and calcium homeostasis. Biochim Biophys Acta Biomembr 1618:163-174

Wilson RW, Gilmour KM, Henry RP, Wood CM (1996) Intestinal base excretion in the seawater-adapted rainbow trout: a role in acid-base balance? J Exp Biol 199:2331-2343

Wilson RW, Wilson JM, Grosell M (2002) Intestinal bicarbonate secretion by marine teleost fish-why and how? Biochim Biophys Acta Biomembr 1566:182-193

Wood CM, Bucking C, Fitzpatrick J, Nadella S (2007a) The alkaline tide goes out and the nitrogen stays in after feeding in the dogfish shark, Squalus acanthias. Respir Physiol Neurobiol 159:163-170

Wood CM, Kajimura M, Bucking C, Walsh PJ (2007b) Osmoregulation, ionoregulation and acid-base regulation by the gastrointestinal tract after feeding in the elasmobranch (Squalus acanthias). J Exp Biol 210:1335-1349 